\title{
Energy Management and Planning in Smart Cities
}

\author{
C. F. Calvillo ${ }^{1 *}$, A. Sánchez-Miralles ${ }^{1}, J_{\text {J }}$ Villar $^{1}$
}

${ }^{1}$ Institute for Research in Technology (IIT)

ICAI School of Engineering, Comillas Pontifical University

Santa Cruz de Marcenado 26, 28015, Madrid, Spain

\section{* Corresponding author}

Email addresses: christian.calvillo@iit.comillas.edu (C.F. Calvillo), alvaro@comillas.edu (A. Sánchez-Miralles), jose.villar@,iit.comillas.edu (J. Villar)

\begin{abstract}
A smart city is a sustainable and efficient urban centre that provides a high quality of life to its inhabitants through optimal management of its resources. Energy management is one of the most demanding issues within such urban centres owing to the complexity of the energy systems and their vital role. Therefore, significant attention and effort need to be dedicated to this problem. Modelling and simulation are the major tools commonly used to assess the technological and policy impacts of smart solutions, as well as to plan the best ways of shifting from current cities to smarter ones.

This paper reviews energy-related work on planning and operation models within the smart city by classifying their scope into five main intervention areas: generation, storage, infrastructure, facilities, and transport. More-complex urban energy models integrating more than one intervention area are also reviewed, outlining their advantages and limitations, existing trends and challenges, and some relevant applications. Lastly, a methodology for developing an improved energy model in the smart-city context is proposed, along with some additional final recommendations.
\end{abstract}


C. Calvillo, A. Sánchez, J. Villar. Energy management and planning in smart cities. Renewable \& Sustainable Energy Reviews. vol. 55, pp. 273-287, March 2016. JCR: 8.050 (2016)

Keywords: Smart City; Renewable Sources; Energy Storage; Smart Grid; Distributed Energy Resources; Transport Systems.

\section{Introduction}

The smart city is a relatively new concept that has been defined by many authors and institutions and used by many more. In a very simple way, the smart city is intended to deal with or mitigate, through the highest efficiency and resource optimization, the problems generated by rapid urbanization and population growth, such as energy supply, waste management, and mobility. Many classifications of smart-city intervention areas can be found in the literature, as in [1] and [2]. A drawback of these classifications is that they categorize energy mainly based on the smart grid, overlooking other relevant energy elements, like transport and facilities.

Cities' energy requirements are complex and abundant. In consequence, modern cities should improve present systems and implement new solutions in a coordinated way and through an optimal approach, by profiting from the synergies among all these energy solutions. The intermittency of renewable sources, the increasing demand, and the necessity of energyefficient transport systems, among other things, represent important energy challenges that are better addressed as a whole [3] rather than separately, as is usually the case.

Simulation models have been developed to assist stakeholders in understanding urban dynamics and in evaluating the impact of energy-policy alternatives. However, very often these efforts address energy areas separately, lacking the "full picture" and, therefore, producing suboptimal solutions. A comprehensive smart-city model that includes all energyrelated activities while keeping the size and complexity of the model manageable is highly desirable in order to successfully meet the increasing energy needs of present and future cities.

This work proposes five main energy-related activities that have been called intervention areas (see Fig. 1): generation, storage, infrastructure, facilities, and transport (mobility). All 
C. Calvillo, A. Sánchez, J. Villar. Energy management and planning in smart cities. Renewable \& Sustainable Energy Reviews. vol. 55, pp. 273-287, March 2016. JCR: 8.050 (2016)

these areas are related to each other but contribute to the energy system in different ways: generation provides energy, while storage helps in securing its availability; infrastructure involves the distribution of energy and user interfaces; facilities and transport are the main final consumers of energy, as they need it to operate. Energy systems' implementations are supported by three main layers: intelligence (control/management), communication, and hardware (physical elements and devices). Hence, multidisciplinary solutions are expected. This research mainly focuses on the hardware and intelligence layers.

This paper has two main objectives. The first is to develop insight into the complexity of the energy-related activities in a smart-city context by reviewing advances and trends and by analysing the synergies among different intervention areas. Moreover, some of the most typical applications found in the literature for the various energy areas, as well as operation and planning tools, are reviewed. The second objective is to assist stakeholders and policymakers in the design of energy solutions for smart cities by providing strategies for the effective modelling and management of energy systems and by reviewing existing projects and software tools. These strategies include the most relevant elements and common sources of information required for their mathematical modelling.

This paper comprises two parts: the first (sections 2-6) presents a review of the research developed in the proposed intervention areas involving energy in smart cities. Section 2 addresses advances in energy generation in a smart-city context, section 3 reviews several storage systems and their applications, section 4 analyses the actual state of the technology and perspectives in the area of infrastructure, section 5 presents energy-related technologies and systems implemented in facilities, and section 6 analyses the advances in energy consumption of transport systems. The second part comprises section 7; it reviews current energy-modelling approaches for smart cities and proposes a methodology for energy-system planning and operation. Finally, concluding remarks and recommendations can be found in section 8 . 
C. Calvillo, A. Sánchez, J. Villar. Energy management and planning in smart cities. Renewable \& Sustainable Energy Reviews. vol. 55, pp. 273-287, March 2016. JCR: 8.050 (2016)

\section{Generation}

From an energy-generation perspective, two main research lines are attracting the most attention. On one hand, renewable-energy sources entail a mid- to long-term investment for energy self-sufficiency without compromising future generations [3], although other nonrenewable sources, such as combined heat and power (CHP) with natural gas and biomass generation (considering that these alternatives are less polluting than conventional generation [22], [101]), can also be a suitable short-term alternative for reducing emissions and meeting the energy demand [4]. On the other hand, distributed generation (DG) is gaining interest as a tool to increase efficiency and to support grid reliability and resiliency [5]. The benefits and requirements of DG have been studied widely [6], [8].

It is important to note that the smart city should gradually migrate to a full renewable-energy scheme, a goal that can be facilitated by DG. Hence, although conventional generation will still be present in smart cities in the short to medium term, it is not addressed in this section.

\subsection{Generation technology review}

Different generation solutions can be successfully implemented in a smart city; Table 1 summarizes important characteristics of the studied technologies. 
C. Calvillo, A. Sánchez, J. Villar. Energy management and planning in smart cities. Renewable \& Sustainable Energy Reviews. vol. 55, pp. 273-287, March 2016. JCR: 8.050 (2016)

Table 1. Comparison of most common distributed energy sources

\begin{tabular}{|c|c|c|c|c|c|}
\hline \multirow[t]{2}{*}{ Generator } & \multicolumn{2}{|c|}{ Generated Power } & \multirow[t]{2}{*}{ Dispatchable } & \multirow[t]{2}{*}{ Efficiency } & \multirow{2}{*}{$\begin{array}{l}\text { Common } \\
\text { application } \dagger\end{array}$} \\
\hline & electric & thermal & & & \\
\hline Solar PV & Yes & No & No & Low $(<30 \%)$ & $\mathrm{Hh}, \mathrm{B}$ \\
\hline Solar TC & No & Yes & No & $\begin{array}{l}\text { Moderate } \\
(<=60 \%)\end{array}$ & $\mathrm{Hh}, \mathrm{B}$, \\
\hline Solar CSP & Yes $^{*}$ & Yes & Yes & $\begin{array}{l}\text { Moderate } \\
(<=60 \%)\end{array}$ & (D)t/(D, P)e \\
\hline Solar PV/T & Yes & Yes & No & $\begin{array}{l}\text { Moderate } \\
(<=60 \%)\end{array}$ & $\mathrm{Hh}, \mathrm{B}, \mathrm{D}$ \\
\hline Windpower & Yes & No & No & $\begin{array}{l}\text { Moderate } \\
(<=60 \%)\end{array}$ & $\mathrm{D}, \mathrm{P}$ \\
\hline Poly-gen. & Yes & Yes & Yes & High (>60\%) & $\mathrm{B}, \mathrm{D}$ \\
\hline Biomass & Yes & Yes & Yes & $\begin{array}{l}\text { Moderate } \\
(<=60 \%)\end{array}$ & $\begin{array}{l}(\mathrm{Hh}, \mathrm{B}, \mathrm{D}) \mathrm{t} / \\
(\mathrm{D}, \mathrm{P}) \mathrm{e}\end{array}$ \\
\hline Geothermal & Yes $^{*}$ & Yes & Yes & High $(>60 \%)$ & $\begin{array}{l}(\mathrm{Hh}, \mathrm{B}, \mathrm{D}) \mathrm{t} / \\
(\mathrm{D}, \mathrm{P}) \mathrm{e}\end{array}$ \\
\hline
\end{tabular}

$\dagger$ Hh: Household, B: Building, D: District, P: Power plant.

Photovoltaic (PV) panels convert solar energy into direct-current electricity using semiconducting materials. They have been extensively studied and highly preferred in smallscale generation, mainly owing to the significant cost reduction in recent years resulting from the competitive values of the levelized cost of energy (LCOE) [33], [34]

Thermal collectors (TCs) collect heat by absorbing sunlight. They have been proved a reliable source for heating water or any other heat-transfer fluid for any kind of application [11]. TCs have affordable prices on a small scale, and can be implemented as concentrated solar-power (CSP) plants for utility-scale electricity generation [12]; they are normally used with some sort of thermal generation. This kind of generation has a competitive LCOE; nevertheless, it is not suitable in cities. In addition, photovoltaic-thermal collectors (PV/T) work as regular PV cells but also deliver thermal energy in order to heat water or other fluids. $\mathrm{PV} / \mathrm{Ts}$ have high efficiency, but there are few commercial modules, and these exist only in small scale [13].

Wind turbines (WT) are used to extract power from an air flow to produce mechanical or electrical power. This is a mature technology with a wide variety in system sizes, producing cheap energy at the utility scale. However, such technology is expensive on a small scale, 
C. Calvillo, A. Sánchez, J. Villar. Energy management and planning in smart cities. Renewable \& Sustainable Energy Reviews. vol. 55, pp. 273-287, March 2016. JCR: 8.050 (2016)

and owing to wind's high unpredictability, turbines are commonly accompanied by other energy sources or storage systems [130] when used in small applications.

Biomass has become a topic of increasing importance in recent years. It is a versatile energy source that can be used directly via combustion to produce heat or indirectly after converting it to a gaseous or liquid biofuel capable of providing heat or electricity at competitive prices [14]. However, farming biomass crops needs to be done responsibly in order to be sustainable. Indeed, new European directives cap the first-generation biofuels, made with sugars and vegetable oils found in arable crops, while favouring the second-generation biomass compound of woody crops, agricultural residues, and waste [15].

Geothermal energy derives from the thermal energy flux from the centre of the earth and can be used only for thermal production (low-medium temperatures) or co-generation (high temperatures). Geothermal electricity is very cheap when the proper ground conditions are met, although not many cities have those soil characteristics [16].

Finally, poly-generation, or multi-generation, emerged as an effort to use fossil fuels more efficiently by delivering different kinds of energy vectors from a single source of fuel (usually natural gas that is burnt to produce electricity; the waste heat is used for other purposes). Along with increasing overall efficiency, this approach also reduces $\mathrm{CO}_{2}$ emissions [4]. The main disadvantage of this technology is its elevated cost on a very small scale [17]. For instance, hydrogen fuel cells represent one of the technologies available for very small applications, but the cost of the produced energy is higher than that of conventional generation [139].

\subsection{Distributed generation applications and tools}

One of the main research challenges related to DG is determining of the optimal configuration, location, type and sizing of the generation units, so that the system meets the energy requirements at minimum cost [18]. Reference [19] reviews most of the design aspects for hybrid DG systems, such as sizing methodologies, integration configurations (DC 
C. Calvillo, A. Sánchez, J. Villar. Energy management and planning in smart cities. Renewable \& Sustainable Energy Reviews. vol. 55, pp. 273-287, March 2016. JCR: 8.050 (2016)

coupled or AC coupled or hybrid DC-AC coupled), and reference [20] analyses controlsystem arrangements (centralized, decentralized, or hybrid).

From the examples found in the literature, it is clear that many DG schemes contain hybrid systems with more than one generation source. For instance, solar power is used for thermal and electric generation in buildings, as demonstrated in [21]. Despite the fact that the former also analyses geothermal heat pumps (GHP), it does not consider other applicable sources, and the cost estimations are unclear. Natural-gas-fuelled poly-generation is studied in [22], which proposes a general model for estimating the energy and $\mathrm{CO}_{2}$-emission performance but disregards economic aspects or comparison with other technologies. Reference [23] presents a feasibility analysis of GHP, PV, and other co-generation technologies for buildings, but the level of detail in the system models, demand profiles, and energyproduction calculation might be insufficient for an accurate economic analysis. Unlike previous examples that consider only one or two sources, other works, such as [24] and [25], model several DG technologies and analyse their economic and technical feasibility. The former proposes an analytical method for the sizing of DG systems, while the latter proposes a linear programming problem. Both studies analyse DG systems following a single-node approach.

Unlike previous applications that design their DG systems according to their own methodology, other interesting applications use specialized software tools for this purpose. Indeed, [26] reviews 37 different computer tools that can be used to analyse the integration of renewable energy. One such tool that stands out is HOMER [29]. This software, developed by the National Renewable Energy Laboratory [27], is quite popular and is used extensively in the literature. For instance, reference [28] presents a HOMER application of optimal DG planning for microgrids in Serbia. The authors find the optimal technology mix under different scenarios of $\mathrm{CO}_{2}$-reduction constraints, considering CHP, micro-hydro, PV, and WT systems. Another similar tool is DERCAM, developed by Berkeley Lab [30], one application of which is assessing the impact of electric vehicles (EVs) on other distributed energy resources (DER) solutions considering uncertainty in EV driving schedules [31]. A 
C. Calvillo, A. Sánchez, J. Villar. Energy management and planning in smart cities. Renewable \& Sustainable Energy Reviews. vol. 55, pp. 273-287, March 2016. JCR: 8.050 (2016)

summary of several other interesting applications that use these tools can be found in [29], [20], and [18]; many are real-life implementations of DG systems.

It is important to note that all the software tools available have been comprehensively reviewed in the literature following different approaches, as in [121], [128], and [26]. Indeed, most of the reviewed tools are used to model electricity systems; some also include the heat or transport sectors, but with some limitations in terms of application and technologies used. It is stated in [26] that only three tools include electricity, heat, and transport capabilities, and these have been used to model $100 \%$ renewable systems (no conventional generation). However, these tools do not consider all the relevant transport and generation technologies or storage systems present in a city, and they are designed to attain certain specific objectives, such as evaluating the effects of particular promotion schemes, which might be difficult to apply to solve other problems.

As mentioned earlier, these models have been developed with different focuses and objectives, so the technologies considered and the level of detail and features of the models can change the outcome. For instance, the authors of [31] use time steps of one hour and a simulation length of one year, as the objective of the study is to find the optimal DER investment and operation scheduling. Conversely, reference [149] studies the optimal operation of residential appliances within five-minute time slots, considering the uncertainty of electricity prices. This paper, unlike the previous one, focuses more on real-time operation than on investment planning; hence, the difference in level of detail (time intervals). Another interesting example is reference [29], whose authors analyse the same DG case study using two different software tools (HOMER and RETScreen) and note that the outcomes are considerably different in terms of DG production given the same inputs. Therefore, the appropriate model or tool should be selected with caution, checking whether the chosen software has the required features and outcomes for the desired application.

Regarding the applicability of DG, several pieces of research focus on the technical issues of such technologies. For instance, reference [147] presents an extensive review of flexible AC transmission systems (FACTS) and DG systems and their impacts on the network, addressing 
C. Calvillo, A. Sánchez, J. Villar. Energy management and planning in smart cities. Renewable \& Sustainable Energy Reviews. vol. 55, pp. 273-287, March 2016. JCR: 8.050 (2016)

different methodologies for placement and coordinated control schemes for such systems. Other non-technical challenges for DG systems are reviewed in [148], which notes that competitive mechanisms and regulatory measures can assist the implementation of DG in a cost-effective way. This paper includes real-case studies of four locations in the United States.

Table 2 summarizes all the DG applications just mentioned, organized by technology. Some references appear several times, as they analyse different DG technologies separately. The table shows that the kind of results obtained and the way of presenting them differ among studies; for example, not all of them include $\mathrm{CO}_{2}$-emission-reduction information. The economic results, such as the payback time or the expected benefits (equivalent to the return on investment $[\mathrm{ROI}])$, of different works can also vary significantly, especially considering the year when the study was carried out and specific pricing considerations. Therefore, these economic metrics and studies can be used to compare various systems and methodologies, but this kind of comparison should be undertaken with caution. 
C. Calvillo, A. Sánchez, J. Villar. Energy management and planning in smart cities. Renewable \& Sustainable Energy Reviews. vol. 55, pp. 273-287, March 2016. JCR: 8.050 (2016)

Table 2. Summary of DG application examples.

\begin{tabular}{|c|c|c|c|c|c|c|c|}
\hline Technology & Ref. & $\begin{array}{l}\text { System } \\
\text { dimensioning } \\
\text { methodology }\end{array}$ & $\begin{array}{l}\text { Expected } \\
\text { benefits } \\
(\%)^{*}\end{array}$ & $\begin{array}{l}\mathrm{CO}_{2} \\
\text { reduction } \\
(\%)^{* *}\end{array}$ & $\begin{array}{l}\text { Energy } \\
\text { supplied } \\
\text { (\%) }\end{array}$ & $\begin{array}{l}\text { Payback } \\
\text { time } \\
\text { (years) }\end{array}$ & $\begin{array}{l}\text { Study } \\
\text { year }\end{array}$ \\
\hline PV & [21] & $\begin{array}{l}\text { Graphic } \\
\text { construction }\end{array}$ & N/A & $43,4 \%$ & $53 \%$ & 12.5 & 2011 \\
\hline PV & {$[24]$} & $\begin{array}{l}\text { Graphic } \\
\text { construction }\end{array}$ & $<1 \%$ & $\mathrm{~N} / \mathrm{A}$ & $22.8 \%$ & 14 & 2013 \\
\hline PV & [25] & Optimization & $\begin{array}{l}3,5- \\
10,4 \%\end{array}$ & $\mathrm{~N} / \mathrm{A}$ & $\mathrm{N} / \mathrm{A}$ & $\mathrm{N} / \mathrm{A}$ & 2013 \\
\hline $\mathrm{TC}$ & {$[21]$} & $\begin{array}{l}\text { Graphic } \\
\text { construction }\end{array}$ & $\mathrm{N} / \mathrm{A}$ & $20 \%$ & $58 \%$ & 7 & 2011 \\
\hline $\mathrm{TC}$ & {$[24]$} & $\begin{array}{l}\text { Graphic } \\
\text { construction }\end{array}$ & $<1 \%$ & $\mathrm{~N} / \mathrm{A}$ & $65 \cdot 3 \%$ & 17,7 & 2013 \\
\hline $\mathrm{TC}$ & {$[25]$} & Optimization & $8,8 \%$ & $\mathrm{~N} / \mathrm{A}$ & $\mathrm{N} / \mathrm{A}$ & $\mathrm{N} / \mathrm{A}$ & 2013 \\
\hline WT & [24] & $\begin{array}{l}\text { Graphic } \\
\text { construction }\end{array}$ & $<1 \%$ & $\mathrm{~N} / \mathrm{A}$ & $66.6 \%$ & 15,5 & 2013 \\
\hline WT & {$[25]$} & Optimization & $1-18,8 \%$ & $\mathrm{~N} / \mathrm{A}$ & $\mathrm{N} / \mathrm{A}$ & $\mathrm{N} / \mathrm{A}$ & 2013 \\
\hline $\mathrm{CHP}$ & [22] & Analytical & $20 \%$ & $40 \%$ & $\mathrm{~N} / \mathrm{A}$ & $\mathrm{N} / \mathrm{A}$ & 2008 \\
\hline CHP & [24] & $\begin{array}{l}\text { Graphic } \\
\text { construction }\end{array}$ & $<2 \%$ & $\mathrm{~N} / \mathrm{A}$ & $100 \%$ & 9.5 & 2013 \\
\hline $\mathrm{CHP}$ & [28] & $\begin{array}{l}\text { SW tool } \\
\text { (HOMER) }\end{array}$ & $9.08 \%$ & $10 \%$ & $\mathrm{~N} / \mathrm{A}$ & 10 & 2014 \\
\hline $\mathrm{CHP}$ & {$[25]$} & Optimization & $1-2 \%$ & $\mathrm{~N} / \mathrm{A}$ & $\mathrm{N} / \mathrm{A}$ & $\mathrm{N} / \mathrm{A}$ & 2013 \\
\hline $\mathrm{HP}$ & {$[23]$} & Analytical & $2 \%$ & $16 \%$ & $100 \%$ & $\mathrm{~N} / \mathrm{A}$ & 2011 \\
\hline GHP & [23] & Analytical & $4 \%$ & $48 \%$ & $100 \%$ & $\mathrm{~N} / \mathrm{A}$ & 2011 \\
\hline GHP & [21] & $\begin{array}{l}\text { Graphic } \\
\text { construction }\end{array}$ & N/A & $28,7 \%$ & $100 \%$ & 8.5 & 2011 \\
\hline GHP & {$[24]$} & $\begin{array}{l}\text { Graphic } \\
\text { construction }\end{array}$ & $<2 \%$ & $\mathrm{~N} / \mathrm{A}$ & $100 \%$ & 19,4 & 2013 \\
\hline GHP & [25] & Optimization & $13,8 \%$ & $\mathrm{~N} / \mathrm{A}$ & $\mathrm{N} / \mathrm{A}$ & N/A & 2013 \\
\hline CHP, HP & {$[23]$} & Analytical & $43 \%$ & $24 \%$ & $100 \%$ & $\mathrm{~N} / \mathrm{A}$ & 2011 \\
\hline CHP, GHP & [23] & Analytical & $43 \%$ & $41 \%$ & $100 \%$ & $\mathrm{~N} / \mathrm{A}$ & 2011 \\
\hline GHP, PV & [23] & Analytical & $88 \%$ & $99 \%$ & $\mathrm{~N} / \mathrm{A}$ & 11 & 2011 \\
\hline $\begin{array}{l}\mathrm{CHP}, \mathrm{PV}, \\
\text { microhydro }\end{array}$ & {$[28]$} & $\begin{array}{l}\text { SW tool } \\
\text { (HOMER) }\end{array}$ & $10.1 \%$ & $50 \%$ & $\mathrm{~N} / \mathrm{A}$ & 11,1 & 2014 \\
\hline $\begin{array}{l}\mathrm{CHP}, \\
\text { microhydro, } \\
\mathrm{PV}, \mathrm{WT}\end{array}$ & [28] & $\begin{array}{l}\text { SW tool } \\
\text { (HOMER) }\end{array}$ & $6.92 \%$ & $97 \%$ & $\mathrm{~N} / \mathrm{A}$ & 13.5 & 2014 \\
\hline $\mathrm{PV}, \mathrm{CHP}$ & [31] & $\begin{array}{l}\text { SW tool } \\
\text { (DERCAM) }\end{array}$ & $7,7 \%$ & $28,3 \%$ & $\mathrm{~N} / \mathrm{A}$ & 12 & 2014 \\
\hline PV, CHP, EV & [31] & $\begin{array}{l}\text { SW tool } \\
\text { (DERCAM) }\end{array}$ & $9,3 \%$ & $24,1 \%$ & $\mathrm{~N} / \mathrm{A}$ & 12 & 2014 \\
\hline
\end{tabular}

In general, optimization approaches obtain better expected benefits than other methodologies do. Hence, as remarked in [18], the optimal sizing of these renewable-energy-based systems 
C. Calvillo, A. Sánchez, J. Villar. Energy management and planning in smart cities. Renewable \& Sustainable Energy Reviews. vol. 55, pp. 273-287, March 2016. JCR: 8.050 (2016)

can significantly improve their economic and technical performance, while promoting the widespread use of such environmentally friendly sources.

\section{Energy Storage}

Energy storage systems (ESSs) can be used to store several kinds of energy (e.g., electric, thermal, kinetic). Within smart cities, ESSs are mainly expected to serve two purposes: the integration of renewable sources and the delivery of demand-response schemes. Indeed, ESSs can store clean energy from renewable sources when it is produced and not needed (and is usually also cheaper), saving it for use when it is most needed (and more expensive) [43], thus smoothing net load shape and contributing to cleaner and more-efficient energy production [42]. In the same way, electric ESSs can participate in demand-response schemes by locally managing the demand curve, smoothing peaks and valleys. This can contribute to covering new energy loads, such as DC buildings and EVs [44].

\subsection{Storage technologies}

Batteries store electricity as chemical energy, and they are a long-established technology with a high presence in many applications. They are built from one or more electrochemical cells composed of various elements, such as the mature lead-acid ( $\mathrm{Pb}$-acid) system, or using more recent ones such as sodium-sulphur, sodium-nickel chloride, and lithium-ion systems. Their main disadvantages are high prices, possible environmental hazards, limited life cycle, and voltage and current limitations [45]. Nevertheless, several battery chemistries have seen a remarkable cost reduction in recent years, and it is expected that this trend will continue [150].

In applications where a fast response is needed and large amounts of energy must be released in a short time - for instance, in medium-scale power-quality systems - superconducting magnetic energy storage (SMES), the super-capacitor, and the flywheel find their niche. The first technology is a large superconducting coil that stores electric energy in the magnetic field generated by a DC flow [45]. The second one is a double-layer capacitor designed to 
C. Calvillo, A. Sánchez, J. Villar. Energy management and planning in smart cities. Renewable \& Sustainable Energy Reviews. vol. 55, pp. 273-287, March 2016. JCR: 8.050 (2016)

charge and discharge at very high current [47]. It is important to note that this technology is mainly used for grid stability and power quality, not for real energy storage. The third one is a mechanical rotatory device that stores kinetic energy [46]. These technologies also have very long lifecycles but a much higher cost than batteries, and they can provide energy only for very short periods [47].

Hydroelectric (hydro-pumping) storage is commonly used in many countries. It uses the potential energy of water pumped from a lower- to a higher-elevation reservoir to later produce electricity by passing it through a turbine [48]. These systems are commonly used by utilities and systems operators for load balancing, but they have important disadvantages in small-scale applications, such as large unit sizes and topographic and environmental limitations [45].

Hydrogen can be used to produce electricity in fuel cells, gas boilers, or gas turbines. After combustion in a mixture with oxygen, the exhausted gas is water vapour with no polluting emissions. Hydrogen gas has to be artificially produced from other compounds, such as water [49], or from fossil fuels in pre-combustion $\mathrm{CO}_{2}$-capture processes by transforming carbon fuel into a clean, carbonless fuel. The inconvenience of this is that both alternatives are costly and energy inefficient [50].

Compressed-air energy storage (CAES) is another way to store energy at the utility scale. Energy is stored as compressed air, and the storage vessel is often an underground cavern [53]. Like hydro storage, this kind of ESS is commonly subject to topographic limitations.

From the foregoing technology descriptions, one can conclude that not all ESSs are appropriate for all applications, as they differ in response time, power or storage capacity, size, and price. The applications for ESSs can be classified into three groups by discharge time: bulk storage $(1-8 \mathrm{~h})$ for load levelling or spinning reserve; DG storage $(0.5-4 \mathrm{~h})$ for integration of distributed renewable sources, peak shaving, transmission deferral, and so on; and power-quality storage (1-30s) for end-use power quality and reliability [48]. Table 3 
C. Calvillo, A. Sánchez, J. Villar. Energy management and planning in smart cities. Renewable \& Sustainable Energy Reviews. vol. 55, pp. 273-287, March 2016. JCR: 8.050 (2016)

summarizes ESS technologies and proposes their most potentially effective applications [44], [48], [134].

Table 3. Comparison of common electric storage technologies.

\begin{tabular}{|c|c|c|c|c|c|c|}
\hline \multirow[b]{2}{*}{ Type } & \multirow[b]{2}{*}{ Eff. (\%) } & \multicolumn{2}{|l|}{ Density } & \multirow{2}{*}{$\begin{array}{l}\text { Resp. } \\
\text { time } \\
(\mathrm{ms})\end{array}$} & \multirow[b]{2}{*}{$\begin{array}{l}\text { Cycle life } \\
\text { (time) }\end{array}$} & \multirow[b]{2}{*}{ App. * } \\
\hline & & $\begin{array}{l}\text { Energy } \\
\text { (wh/kg) }\end{array}$ & $\begin{array}{l}\text { Power } \\
\text { (w/kg) }\end{array}$ & & & \\
\hline Battery & $60-90$ & $20-200$ & $25-1000$ & 30 & $\begin{array}{l}200- \\
10000^{* *}\end{array}$ & $\mathrm{~B}, \mathrm{DG}$ \\
\hline SMES & $95-98$ & $30-100$ & $1 \mathrm{e} 4-1 \mathrm{e} 5$ & 5 & $1 \mathrm{e} 6$ & PQ \\
\hline Flywheel & 95 & $5-50$ & $1 \mathrm{e} 3-5 \mathrm{e} 3$ & 5 & $>20000$ & $\mathrm{DG}, \mathrm{PQ}$ \\
\hline Super Capacitor & 95 & $<50$ & 4000 & 5 & $>50000$ & PQ \\
\hline CAES & $70-80$ & $\mathrm{~N} / \mathrm{A}$ & $\mathrm{N} / \mathrm{A}$ & $>1 \mathrm{e} 3$ & $>1 \mathrm{e} 6$ & $\mathrm{~B}$ \\
\hline Hydroelectric & $70-85$ & $\mathrm{~N} / \mathrm{A}$ & $\mathrm{N} / \mathrm{A}$ & $>1 \mathrm{e} 3$ & $>1 e 6$ & $\mathrm{~B}$ \\
\hline
\end{tabular}

* B: bulk storage; DG: distributed gen. storage; PQ: power quality storage.

** the number of cycles heavily depends on the kind of chemistry of the battery.

Thermal storage systems use a fluid or other material in a reservoir to store thermal energy for later use. The most common use of these ESSs in smart cities involves water tanks that are capable of meeting thermal demand in both residential and commercial facilities [51]. More recently, molten salt tanks have been used, mainly at the utility scale, for hightemperature thermal storage for electricity generation in concentrated solar-power plants $[52]$.

\subsection{Applications and models of ESSs}

Applications for ESSs can be found in a multitude of technologies. The scale and the means of the storage system can also vary widely. On a large scale, reference [53] analyses the economic feasibility of CAES for increasing the grid integration of wind generation in the German power system. On a small to medium scale, most research works include batterybased systems for integrating renewable energy sources, as in [54]. However, other ESS technologies are also considered, focusing more on power quality. For instance, [46] presents a wind-diesel power system, including flywheel storage for isolated microgrid applications. Similarly, reference [47] analyses super-capacitor banks for load frequency control in power systems. 
C. Calvillo, A. Sánchez, J. Villar. Energy management and planning in smart cities. Renewable \& Sustainable Energy Reviews. vol. 55, pp. 273-287, March 2016. JCR: 8.050 (2016)

Other interesting approaches include hybrid storage systems, combining different storage technologies in order to reduce the limitations of the independent devices and to improve overall performance. In [44], the benefits of hybrid ESSs are studied in a microgrid context, and in [55], a hybrid flywheel-battery system is presented for EV applications, emphasizing the power electronics and control requirements.

Plug-in EVs represent another major application of ESSs, and many related studies can be found in the literature. In this area, most work focuses on the charge/discharge control of EV fleets, as stated in [56], where a review of different smart-charging strategies is presented. In addition, the advantages and drawbacks of centralized and decentralized control are analysed.

Smart-charging strategies can have different objectives. For instance, examples of renewable-energy integration assisted by EV technology are listed in [129]. Other interesting related research can be found in [57], where the impact on the grid of high penetration of EVs in two real distribution areas is assessed. A similar approach is presented in [58], which examines not only load balancing but also the impact of a large penetration of EVs on energy prices and analyses thermal-generation dispatch decisions. A different approach is presented in [59], where used EV batteries are installed as stationary energy storage for a microgrid, and the system's economic feasibility is analysed. In contrast to previous references, which mainly focus on the economic impact of ESSs, considering with little detail important characteristics such as battery degradation, the authors of reference [60] present a detailed degradation model of the lithium-ion batteries for EV application and propose charging strategies to maximize battery life cycle.

With respect to thermal storage, most research is related to the optimal usage and control of thermal energy for buildings. Reference [61] presents an electric thermal ESS governed by electricity price signals. In [51], a complex predictive control system with water thermal storage is proposed and then compared with other control methods. Additionally, solar TC and co-generation systems commonly comprise thermal storage for residential and commercial use, as in [21] and [22]. 
C. Calvillo, A. Sánchez, J. Villar. Energy management and planning in smart cities. Renewable \& Sustainable Energy Reviews. vol. 55, pp. 273-287, March 2016. JCR: 8.050 (2016)

Table 4 summarizes the examples reviewed in this section. It can be seen that the focus of each work varies greatly, although two main applications stand out: the integration of renewable energy (including power quality and the security of supply-related studies) and the integration of EVs (including impact on the grid and vehicle-to-grid [V2G] interaction). 
C. Calvillo, A. Sánchez, J. Villar. Energy management and planning in smart cities. Renewable \& Sustainable Energy Reviews. vol. 55, pp. 273-287, March 2016. JCR: 8.050 (2016)

Table 4. Summary of ESS application examples.

\begin{tabular}{|c|c|c|c|c|c|}
\hline ESS & Ref. & $\begin{array}{l}\text { Other } \\
\text { technologies }\end{array}$ & Proposes & focus & $\begin{array}{l}\text { Reported } \\
\text { outcome }\end{array}$ \\
\hline $\mathrm{EV}$ & [6o] & None & $\begin{array}{l}\text { Charging } \\
\text { control and } \\
\text { degradation } \\
\text { model }\end{array}$ & $\begin{array}{l}\text { Minimize } \\
\text { battery } \\
\text { degradation }\end{array}$ & $\begin{array}{l}6.39 \% \text { less } \\
\text { degradation }\end{array}$ \\
\hline $\mathrm{EV}$ & {$[57]$} & None & $\begin{array}{l}\text { Impact analysis } \\
\text { of high } \\
\text { penetration of } \\
\text { EV }\end{array}$ & $\begin{array}{l}\text { Distribution } \\
\text { network } \\
\text { reinforcement } \\
\text { costs }\end{array}$ & $\begin{array}{l}\text { up to } 15 \% \text { of } \\
\text { increment in total } \\
\text { investment }\end{array}$ \\
\hline $\mathrm{EV}$ & [58] & Hydro & $\begin{array}{l}\text { Impact analysis } \\
\text { of high } \\
\text { penetration of } \\
\text { EV }\end{array}$ & $\begin{array}{l}\text { Energy prices } \\
\text { and load curves }\end{array}$ & $\begin{array}{l}\text { Reduction of } 70 \% \\
\text { of load and } 15 \% \\
\text { of energy prices } \\
\text { at peak hours } \\
\text { with smart } \\
\text { charging }\end{array}$ \\
\hline EV & [31] & PV, CHP & $\begin{array}{l}\text { Planning and } \\
\text { operation of } \\
\text { DER }\end{array}$ & $\begin{array}{l}\text { Maximize } \\
\text { cost/benefit of } \\
\text { DG and ESS }\end{array}$ & $\begin{array}{l}9.3 \% \text { benefits in } \\
\text { energy costs }\end{array}$ \\
\hline Batteries & [59] & None & $\begin{array}{l}\text { Planning and } \\
\text { operation of } \\
\text { ESS }\end{array}$ & $\begin{array}{l}\text { Maximize } \\
\text { cost/benefit of } \\
\text { reused EV } \\
\text { batteries }\end{array}$ & $\begin{array}{l}14.8 \% \text { benefits in } \\
\text { energy costs }\end{array}$ \\
\hline Batteries & [54] & PV & $\begin{array}{l}\text { Integration of } \\
\text { RES }\end{array}$ & $\begin{array}{l}\text { Technical/ } \\
\text { economic } \\
\text { feasibility } \\
\text { analysis }\end{array}$ & $\begin{array}{l}\text { Pros and cons of } \\
\text { different battery } \\
\text { technologies. }\end{array}$ \\
\hline $\begin{array}{l}\text { Batteries, } \\
\text { super } \\
\text { capacitor }\end{array}$ & [44] & None & $\begin{array}{l}\text { System model } \\
\text { and control for } \\
\text { hybrid ESS in } \\
\text { microgrid }\end{array}$ & $\begin{array}{l}\text { Power system } \\
\text { stability }\end{array}$ & $\begin{array}{l}\text { Effective control } \\
\text { system to } \\
\text { maintain power } \\
\text { quality }\end{array}$ \\
\hline $\begin{array}{l}\text { Batteries, } \\
\text { flywheel }\end{array}$ & {$[55]$} & None & $\begin{array}{l}\text { System model } \\
\text { and control for } \\
\text { hybrid ESS in } \\
\text { EV applications }\end{array}$ & $\begin{array}{l}\text { Power quality } \\
\text { and efficiency }\end{array}$ & $\begin{array}{l}\text { Average efficiency } \\
\text { of } 87 \% \text {, unity } \\
\text { power factor and } \\
\text { low distortion. }\end{array}$ \\
\hline Flywheel & [46] & $\begin{array}{l}\text { WT, Diesel } \\
\text { generator. }\end{array}$ & $\begin{array}{l}\text { System model } \\
\text { and control for } \\
\text { ESS in } \\
\text { microgrid }\end{array}$ & $\begin{array}{l}\text { Power quality } \\
\text { and system } \\
\text { stability }\end{array}$ & $\begin{array}{l}44 \% \text { less } \\
\text { frequency } \\
\text { variation. }\end{array}$ \\
\hline $\begin{array}{l}\text { Super- } \\
\text { capacitor }\end{array}$ & [47] & None & $\begin{array}{l}\text { System model } \\
\text { and control for } \\
\text { ESS }\end{array}$ & Power quality & $\begin{array}{l}\text { Almost } 80 \% \\
\text { reduction in peak } \\
\text { frequency } \\
\text { deviation }\end{array}$ \\
\hline CAES & [53] & WT & $\begin{array}{l}\text { System model of } \\
\text { ESS }\end{array}$ & $\begin{array}{l}\text { Economic } \\
\text { feasibility } \\
\text { analysis }\end{array}$ & $\begin{array}{l}\text { Return of } \\
\text { investment in } 13 \\
\text { - } 19 \text { years }\end{array}$ \\
\hline $\begin{array}{l}\text { Thermal } \\
\text { storage }\end{array}$ & [61] & None & $\begin{array}{l}\text { Optimal usage } \\
\text { and control of } \\
\text { thermal energy }\end{array}$ & $\begin{array}{l}\text { Minimize } \\
\text { thermal energy } \\
\text { cost }\end{array}$ & $\begin{array}{l}20-31 \% \text { benefits } \\
\text { in energy costs }\end{array}$ \\
\hline $\begin{array}{l}\text { Thermal } \\
\text { storage }\end{array}$ & [51] & None & $\begin{array}{l}\text { Optimal usage } \\
\text { and control of } \\
\text { thermal energy }\end{array}$ & $\begin{array}{l}\text { Control method } \\
\text { performance }\end{array}$ & $\begin{array}{l}19 \% \text { better } \\
\text { performance }\end{array}$ \\
\hline
\end{tabular}


C. Calvillo, A. Sánchez, J. Villar. Energy management and planning in smart cities. Renewable \& Sustainable Energy Reviews. vol. 55, pp. 273-287, March 2016. JCR: 8.050 (2016)

\section{Grid Infrastructure}

In this paper, infrastructure mainly refers to the urban power grids. However, apart from the smart-grid concept that covers only electric energy, district energy networks are an interesting example of smart infrastructure, supplying thermal and electric energy to different interconnected facilities [4]. This kind of network is discussed in more detail in the following section.

The electric grid is the energy backbone of any city, and it is used for transmitting energy from generators to consumers with the required quality and reliability. Conventional grids can have technical hitches, however, such as unidirectional protections and a lack of the required communication infrastructure and control systems, and they might not be ready for increasing demand and DG. Therefore, grid-related literature commonly addresses ways to use the current infrastructure efficiently, avoiding unnecessary investments [8].

Similar to the smart-city concept, a smart-grid infrastructure can be defined in many ways. The core of the smart grid consists of implementing modern information and communication technologies, enabling real-time bidirectional communication among all participating entities. Every device and system in a smart grid is expected to provide information about its own energy consumption or production and to follow the commands to schedule its load depending on factors such as system load, prices, and contractual obligations [62].

Some of the main features proposed for a smart grid in [63] include the capacity to meet increasing consumer demand without building new infrastructure; a resilient structure resistant to attacks and natural disasters (with self-healing capacity); a quality-focused power supply with a combined power-source structure, composed of separated energy networks (microgrids) capable of exchanging power and operating separately and independently if necessary; and the implementation of real-time communication between all participant agents, facilitating all these tasks. 
C. Calvillo, A. Sánchez, J. Villar. Energy management and planning in smart cities. Renewable \& Sustainable Energy Reviews. vol. 55, pp. 273-287, March 2016. JCR: 8.050 (2016)

\subsection{Research on and applications of smart-grid infrastructure.}

There is a substantial amount of smart-grid-related research addressing all sorts of problems. This research covers aspects from regulation and business models to power electronics, communication protocols, and control systems. Along with the economic aspects, infrastructure investments are a major concern. Long-term smart-grid investment-planning models are presented in [6], [57], and [65], which calculate the effects of DG or EVs on distribution-network investment planning.

Similarly, adequate regulation and energy markets for smart grids are commonly addressed. For instance, adequate regulatory frameworks and energy markets and services required for demand-response schemes are studied in [62]. However, that study models the smart grids only conceptually, without entering into technical details. Other examples analyse several European projects, such as [66], which studies a market-price mechanism for smart-grid environments.

Infrastructure for integrating renewable resources is another important research topic. Effects on the grid are addressed in [8]. Similarly, energy storage and EV integration are widely studied, as EVs represent a considerable challenge for future power grids. The effects of a large penetration of EVs in utility operation and energy market prices are addressed in [58]. Reference [131] simulates and analyses the number of EVs that can be connected in a region of the German grid, and reference [67] proposes a conceptual regulatory framework for charging EVs, describing business models and the role of the agents involved.

Smart metering is the next step in this direction, and many works describe the advantages of an advanced metering infrastructure. For instance, the energy savings achieved by modifying consumers' behaviour with such systems are estimated in [68]. However, reference [69] discusses not only these possible benefits but also disadvantages, risks, and the prevalent uncertainty regarding the technology.

Reliability and power quality are addressed in [70], which examines the effect of electromagnetic compatibility on the grid, and in [71], which studies the effects of smart 
C. Calvillo, A. Sánchez, J. Villar. Energy management and planning in smart cities. Renewable \& Sustainable Energy Reviews. vol. 55, pp. 273-287, March 2016. JCR: 8.050 (2016)

MV/LV substations in improving continuity of supply in different distribution-network configurations.

Pilot microgrids with smart-grid features have been developed for the simulation and demonstration of DG technologies and control systems. For instance, the LABEIN commercial feeder located in Derio, Spain, comprises more than $5 \mathrm{~kW}$ of PV installations, $6 \mathrm{~kW}$ of WT, two $55 \mathrm{~kW}$ diesel back-up generators, a $50 \mathrm{~kW}$ microturbine, and a variety of electric storage devices. These and other examples of European microgrid implementations can be found in [72].

Table 5 summarizes most of the research examples mentioned in this section. Even though high-scale penetration of smart-grid infrastructure is still a long way off, the tendencies apparent in the reviewed works show that these technologies are gaining presence in many urban centres and could become standard in the long term. 
C. Calvillo, A. Sánchez, J. Villar. Energy management and planning in smart cities. Renewable \& Sustainable Energy Reviews. vol. 55, pp. 273-287, March 2016. JCR: 8.050 (2016)

Table 5. Summary of smart infrastructure application examples.

\begin{tabular}{|c|c|c|c|}
\hline Concern & Ref. & focus & Reported outcome \\
\hline $\begin{array}{l}\text { Impact of DG on } \\
\text { distribution } \\
\text { network } \\
\text { infrastructure. }\end{array}$ & {$[6]$} & $\begin{array}{l}\text { Investment deferral in } \\
\text { the long-term. }\end{array}$ & $\begin{array}{l}\text { With a DG penetration of } 50 \% \text {, } \\
\text { the load can increase } 200- \\
225 \% \text { before adding new } \\
\text { investments. }\end{array}$ \\
\hline $\begin{array}{l}\text { Impact of DG on } \\
\text { distribution } \\
\text { network } \\
\text { infrastructure. }\end{array}$ & {$[65]$} & $\begin{array}{l}\text { Distribution network } \\
\text { costs }\end{array}$ & $\begin{array}{l}\text { With very large DG } \\
\text { penetration, the increment in } \\
\text { total network costs decreases } \\
\text { with a higher level of demand. }\end{array}$ \\
\hline $\begin{array}{l}\text { Impact of DG on } \\
\text { distribution } \\
\text { network } \\
\text { infrastructure. }\end{array}$ & {$[8]$} & $\begin{array}{l}\text { Regulatory aspects for } \\
\text { DG/RES integration. }\end{array}$ & $\begin{array}{l}\text { Remarks the necessity of smart } \\
\text { grid infrastructure, and provides } \\
\text { several recommendations. }\end{array}$ \\
\hline $\begin{array}{l}\text { Impact of EV on } \\
\text { distribution } \\
\text { network } \\
\text { infrastructure. }\end{array}$ & [131] & $\begin{array}{l}\text { Quantity of EVs that } \\
\text { can be integrated in an } \\
\text { existing network }\end{array}$ & $\begin{array}{l}\text { If EVs are charged at the best } \\
\text { locations, a penetration level } \\
\text { of about } 50 \% \text { does not lead to } \\
\text { considerable overloading of } \\
\text { components. }\end{array}$ \\
\hline $\begin{array}{l}\text { Impact of EV on } \\
\text { network } \\
\text { infrastructure. }\end{array}$ & {$[67]$} & $\begin{array}{l}\text { regulatory framework } \\
\text { and business models } \\
\text { for EV charging }\end{array}$ & $\begin{array}{l}\text { Regulatory recommendations } \\
\text { and requirements for } \mathrm{EV} \\
\text { integration. }\end{array}$ \\
\hline $\begin{array}{l}\text { Impact of EV on } \\
\text { distribution } \\
\text { network } \\
\text { infrastructure. }\end{array}$ & [57] & $\begin{array}{l}\text { Investment deferral in } \\
\text { the long-term. }\end{array}$ & $\begin{array}{l}\text { With smart charging strategies, } \\
\text { up to } 60 \%-70 \% \text { of the required } \\
\text { incremental investment can be } \\
\text { avoided. }\end{array}$ \\
\hline $\begin{array}{l}\text { Impact of EV on } \\
\text { network operation. }\end{array}$ & [58] & $\begin{array}{l}\text { energy prices and } \\
\text { thermal generation } \\
\text { dispatch decisions }\end{array}$ & $\begin{array}{l}\text { Smart charging methods reduce } \\
\text { aprox. } 70 \% \text { of peak load and } 15 \% \\
\text { of energy prices at peak hours. }\end{array}$ \\
\hline $\begin{array}{l}\text { Smart grid } \\
\text { demonstration } \\
\text { project in an island } \\
\text { in Denmark. }\end{array}$ & [66] & $\begin{array}{l}\text { Control methodologies } \\
\text { of DER systems for } \\
\text { participation on } \\
\text { energy markets. }\end{array}$ & $\mathrm{N} / \mathrm{A}$ \\
\hline Smart metering & {$[68]$} & $\begin{array}{l}\text { Smart metering } \\
\text { system for Korean } \\
\text { residential } \\
\text { environments. }\end{array}$ & $\begin{array}{l}7.5-15.9 \% \text { of reduction in } \\
\text { energy consumption by just } \\
\text { giving information to the } \\
\text { consumer. }\end{array}$ \\
\hline Smart metering & [69] & $\begin{array}{l}\text { Policy implications of } \\
\text { advanced metering } \\
\text { infrastructure. }\end{array}$ & $\begin{array}{l}\text { Discussion of expected benefits, } \\
\text { possible risks and the } \\
\text { uncertainty related to these } \\
\text { technologies. }\end{array}$ \\
\hline Power Quality & [70] & $\begin{array}{l}\text { Electromagnetic } \\
\text { compatibility }\end{array}$ & $\begin{array}{l}\text { Analysis of the effects on power } \\
\text { quality by the high exposure of } \\
\text { smart grid technologies. }\end{array}$ \\
\hline Security of supply & {$[71]$} & $\begin{array}{l}\text { MV/LV transformer } \\
\text { substation automation }\end{array}$ & $\begin{array}{l}\text { high improvement in } \\
\text { reliability for an automation } \\
\text { degree within the range of } 10 \text { - } \\
35 \%\end{array}$ \\
\hline
\end{tabular}


C. Calvillo, A. Sánchez, J. Villar. Energy management and planning in smart cities. Renewable \& Sustainable Energy Reviews. vol. 55, pp. 273-287, March 2016. JCR: 8.050 (2016)

\section{Facilities}

In this paper, facilities comprise commercial and residential buildings and small-scale infrastructure, but they do not include the industrial sector, which is unlikely to be present within city limits.

In an urban context, buildings are the largest energy consumers. These amenities (considering construction and energy usage) are responsible for approximately three-quarters of total greenhouse-gas emissions in urban areas [3]. Hence, one of the major challenges in smart buildings is minimizing power consumption without compromising users' comfort [76].

The first approach to addressing this energy problem is providing efficient control of the energy systems in buildings. Indeed, optimized operation and management can save between $20 \%$ and $30 \%$ of a building's energy consumption without changing the structure or hardware configuration of the system [73].

Demand response is another popular topic. Nowadays, most buildings are passive consumers of energy. But to achieve the desired energy objectives, the role of the building must change from that of a passive, unresponsive user of energy to that of an active participant in the power system [62]. This paradigm shift can be developed by demand-response schemes facilitated by a microgrid, by applying information and control systems to manage loads and energy consumption, and by taking advantage of DG technologies and energy-storage devices.

Within the overall microgrid concept, other variants have been proposed in the literature, differing especially in scale and type of application. On a small scale (from one household up to a small building or small group of houses), the nanogrid concept appears; [74] defines a nanogrid as a small, isolated DC power system that supplies continuous power to small local loads by using DG and ESS. Other nanogrid approaches also implement an AC power system, as in [73]. On a medium-size scale (neighbourhood, district, or small town), there is no special definition for a microgrid, yet applications of this size deliver a wide range of suitable technologies. The greatest example is the district energy networks, which are 
C. Calvillo, A. Sánchez, J. Villar. Energy management and planning in smart cities. Renewable \& Sustainable Energy Reviews. vol. 55, pp. 273-287, March 2016. JCR: 8.050 (2016)

implemented for distributing energy generated in a centralized location within the district for residential and commercial use. Traditionally, district energy networks have been used exclusively for heating purposes, yet with advances in co-generation, electricity and cooling are being added [4].

Finally, passive systems can be implemented as a complementary approach. These systems are designed to collect, preserve, and distribute thermal energy within a building. Elements to be considered include thermal insulation, thermal mass, window placement and glazing type, and shading (in this context, these factors are commonly referred to collectively as building envelope). However, most of these changes can be considered only for new buildings owing to the high cost of installing them in existing structures [75].

\subsection{Applications and research in facilities}

Significant research has been conducted in the field of home automation (domotics) and control systems for energy and comfort management. Reference [76] includes a comprehensive review of control techniques for smart buildings (energy and comfort management) but without considering energy generation or storage. Within this kind of facility, heat ventilation and air-conditioning systems (HVAC) are the focus of most efforts. For instance, [77] presents an adaptive fuzzy controller for temperature comfort. Besides HVAC, lightning control and features such as appliance control are commonly included, resulting in complex information schemes, as demonstrated in [78].

Demand-response and microgrid-related research has developed considerably in the last several years. Advances in power electronics for nanogrid applications can be found in [79] - specifically, in voltage-source-inverter design and control for DC applications. Controlling and scheduling renewable sources and storage are proposed in [73], with a mixed-integer programming problem for minimizing energy costs in a building, considering dynamic energy prices and demand. Thermal load management in district energy networks is implemented in [51] and [80], including combined heat, cooling and power systems to 
C. Calvillo, A. Sánchez, J. Villar. Energy management and planning in smart cities. Renewable \& Sustainable Energy Reviews. vol. 55, pp. 273-287, March 2016. JCR: 8.050 (2016)

improve energy efficiency. Lastly, milestones and challenges for the commercial large-scale implementation of microgrids are reviewed in [81].

In the passive-systems area, building envelope has been widely researched, producing interesting energy-savings results in heating and air conditioning. In [75], an environmental evaluation of three different wall envelopes is presented, considering different climate scenarios and economic benefits. A similar analysis is developed in [82] for hot and humid locations, comparing different thermal isolations, windows, and shading. Lastly, reference [83] simulates the impact of window design in a hotel building. Most of these considerations must be implemented at the construction stage in order to be cost effective [82], [83].

Table 6 summarizes the examples provided in this section, organized by facility type, and includes generation components and energy systems relative to the reviewed facilities. It can be seen that the smart building focuses on comfort management, energy efficiency, and passive systems. Microgrid research mainly considers demand-response schemes and DG control, whereas district energy networks relate to energy efficiency and load control. It is interesting that several European projects have been commissioned in the infrastructure and facilities areas to address communication issues [84]-[89], demand response [90]-[93], [66] and energy-efficient buildings and districts [94]-[97]. 
C. Calvillo, A. Sánchez, J. Villar. Energy management and planning in smart cities. Renewable \& Sustainable Energy Reviews. vol. 55, pp. 273-287, March 2016. JCR: 8.050 (2016)

Table 6. Summary of facilities application examples.

\begin{tabular}{|c|c|c|c|c|c|}
\hline $\begin{array}{l}\text { Facility } \\
\text { type }\end{array}$ & Ref. & DG/ESS & Proposes & Objective & Reported outcome \\
\hline $\begin{array}{l}\text { Smart } \\
\text { building }\end{array}$ & {$[76]$} & $\mathrm{N} / \mathrm{A}$ & $\begin{array}{l}\text { Control system } \\
\text { for energy } \\
\text { management }\end{array}$ & $\begin{array}{l}\text { User comfort } \\
\text { and energy } \\
\text { usage. }\end{array}$ & $\begin{array}{l}\text { Percentage of People } \\
\text { Dissatisfied index is } \\
\text { less than } 6 \%\end{array}$ \\
\hline $\begin{array}{l}\text { Smart } \\
\text { building }\end{array}$ & {$[77]$} & N/A & $\begin{array}{l}\text { Control system } \\
\text { for energy } \\
\text { management }\end{array}$ & $\begin{array}{l}\text { Reduce energy } \\
\text { consumption }\end{array}$ & $\begin{array}{l}\text { Aprox. } 10-25 \% \\
\text { reduction in energy } \\
\text { consumption }\end{array}$ \\
\hline $\begin{array}{l}\text { Smart } \\
\text { building }\end{array}$ & {$[78]$} & N/A & $\begin{array}{l}\text { Control system } \\
\text { and network } \\
\text { configuration. }\end{array}$ & $\begin{array}{l}\text { Reduce energy } \\
\text { consumption }\end{array}$ & $\begin{array}{l}\text { Power saving of } \\
\text { approximately } 16- \\
24 \%\end{array}$ \\
\hline $\begin{array}{l}\text { Smart } \\
\text { building }\end{array}$ & {$[75]$} & $\mathrm{N} / \mathrm{A}$ & $\begin{array}{l}\text { Comparison of } \\
\text { building } \\
\text { envelope } \\
\text { alternatives }\end{array}$ & $\begin{array}{l}\text { Energy } \\
\text { performance } \\
\text { and payback } \\
\text { time }\end{array}$ & $\begin{array}{l}\text { Ventilated wall has } \\
\text { considerable better } \\
\text { energy performance } \\
\text { than other materials. }\end{array}$ \\
\hline $\begin{array}{l}\text { Smart } \\
\text { building }\end{array}$ & {$[82]$} & $\mathrm{N} / \mathrm{A}$ & $\begin{array}{l}\text { Comparison of } \\
\text { building } \\
\text { envelope } \\
\text { alternatives }\end{array}$ & $\begin{array}{l}\text { Energy } \\
\text { performance }\end{array}$ & $\begin{array}{l}\text { The energy saving } \\
\text { rate of window } \\
\text { materials is up to } \\
33.89 \% \text {. }\end{array}$ \\
\hline $\begin{array}{l}\text { Smart } \\
\text { building }\end{array}$ & {$[83]$} & $\mathrm{N} / \mathrm{A}$ & $\begin{array}{l}\text { Design of } \\
\text { building } \\
\text { envelope } \\
\end{array}$ & $\begin{array}{l}\text { Energy } \\
\text { performance }\end{array}$ & $\begin{array}{l}\text { Up to } 40 \% \text { reduction } \\
\text { on total site energy. }\end{array}$ \\
\hline $\begin{array}{l}\text { Nanogrid/ } \\
\text { microgrid }\end{array}$ & [79] & $\mathrm{N} / \mathrm{A}$ & $\begin{array}{l}\text { Control system } \\
\text { for electronic } \\
\text { converter }\end{array}$ & $\begin{array}{l}\text { Control } \\
\text { performance }\end{array}$ & $\begin{array}{l}\text { Excellent dynamic } \\
\text { performance and low } \\
\text { cross regulation of ac } \\
\text { and dc bus voltages. }\end{array}$ \\
\hline $\begin{array}{l}\text { Nanogrid/ } \\
\text { microgrid }\end{array}$ & [73] & $\begin{array}{l}\text { PV, CHP, } \\
\text { Batteries }\end{array}$ & $\begin{array}{l}\text { Operation of } \\
\text { DER }\end{array}$ & $\begin{array}{l}\text { Minimize } \\
\text { energy costs }\end{array}$ & $\begin{array}{l}6-10 \% \text { of extra } \\
\text { reduced costs by } \\
\text { including battery } \\
\text { storage. }\end{array}$ \\
\hline $\begin{array}{l}\text { District } \\
\text { energy } \\
\text { network }\end{array}$ & {$[51]$} & $\mathrm{N} / \mathrm{A}$ & $\begin{array}{l}\text { Control system } \\
\text { for energy } \\
\text { management }\end{array}$ & $\begin{array}{l}\text { Reduce } \\
\text { thermal energy } \\
\text { consumption }\end{array}$ & $\begin{array}{l}19 \% \text { better } \\
\text { performance on } \\
\text { controller. }\end{array}$ \\
\hline $\begin{array}{l}\text { District } \\
\text { energy } \\
\text { network }\end{array}$ & {$[80]$} & $\mathrm{CHCP}$ & $\begin{array}{l}\text { Comparison of } \\
\text { trigeneration } \\
\text { technologies }\end{array}$ & $\begin{array}{l}\text { Performance } \\
\text { analysis }\end{array}$ & $\begin{array}{l}\text { Proposed system is } \\
10 \% \text { more efficient } \\
\text { than electric } \\
\text { compressor } \\
\text { absorption chillers. }\end{array}$ \\
\hline
\end{tabular}

\section{Transport}

The transport sector is a considerable consumer of energy and one of the main air polluters within cities, creating important health costs [98]. Furthermore, the quality of transport systems in a city directly affects the quality of life for its inhabitants, so future transport systems, both public and private, should be cleaner and more efficient. While the former can 
C. Calvillo, A. Sánchez, J. Villar. Energy management and planning in smart cities. Renewable \& Sustainable Energy Reviews. vol. 55, pp. 273-287, March 2016. JCR: 8.050 (2016)

be achieved by replacing fossil-fuel technologies with reduced-emission vehicles (considered a comparatively cleaner energy source), the latter can be attained by planning and developing better and more-efficient travel routes in order to save energy and time.

\subsection{Advances in transport systems and technologies}

The most popular way to reduce $\mathrm{CO}_{2}$ and other polluting emissions is to replace gasolinepowered vehicles (public or private) with EVs and hybrid EVs; therefore, numerous studies have examined EV technologies that consider charge control, their storage capability, and their impact on the grid, as reviewed in section 3 ("Energy Storage").

A different research line for the transport industry is represented by the use of hydrogen as fuel, where steam is the only exhaust gas. However, creating a hydrogen-supply infrastructure poses a problem, as it will require considerable investment (charging stations, storage tanks, hydrogen-production plants, etc.). Another approach consists of using fuel cells (electric batteries fuelled by hydrogen) in electric cars. The main drawbacks to this are the chemical sustainability of the required compounds and the current price, which is about 10 times higher than that of gasoline per kilowatt of energy [100].

The third alternative is to use biofuels instead of fossil fuels. A key driver of this approach is the possible net fixation of $\mathrm{CO}_{2}$ (i.e., the carbon absorbed by the crop is the same released when burnt); it might even work as a carbon sink [101]. Biofuels can be used in a straightforward way, usually mixed with diesel or gasoline. Using information extracted from [102]-[107], the types of vehicles reviewed are compared in Table 7. It is important to note that real insight into the possible environmental benefits of alternative-fuel vehicles requires an adequate life-cycle analysis. For instance, reference [108] presents the product-life-cycle assessment of an electric drive for automotive applications, assessing the ecological impact of the proposed engine. 
C. Calvillo, A. Sánchez, J. Villar. Energy management and planning in smart cities. Renewable \& Sustainable Energy Reviews. vol. 55, pp. 273-287, March 2016. JCR: 8.050 (2016)

Table 7. Comparison of vehicle technologies.

\begin{tabular}{|l|l|l|l|l|}
\hline Vehicle & $\begin{array}{c}\text { Init. cost } \\
\text { (kUSD) }\end{array}$ & \multicolumn{1}{|c|}{ Efficiency $^{*}$} & $\begin{array}{c}\text { Commercial } \\
\text { availability }\end{array}$ & \multicolumn{1}{|c|}{ Main challenges } \\
\hline EV & 21.3 & High $(>50 \%)$ & Now & $\begin{array}{l}\text { Chemical } \\
\text { sustainability, battery } \\
\text { costs }\end{array}$ \\
\hline HEV & 24.2 & $\begin{array}{l}\text { Moderate } \\
(<=50 \%)\end{array}$ & Now & $\begin{array}{l}\text { Chemical } \\
\text { sustainability, battery } \\
\text { costs }\end{array}$ \\
\hline $\begin{array}{l}\text { Hydrogen } \\
\text { ICE }\end{array}$ & 18 & Low $(<25 \%)$ & In 2-3 years & Lack of infrastructure \\
\hline Fuel-Cell & 40 & Low $(<25 \%)$ & In 2-3 years & $\begin{array}{l}\text { Lack of infras. high } \\
\text { costs }\end{array}$ \\
\hline Biofuels & 17.1 & Low $(<25 \%)$ & Now & $\begin{array}{l}\text { CO }{ }_{2} \text { fixation, } \\
\text { responsible farming }\end{array}$ \\
\hline
\end{tabular}

In addition to the shift to less polluting fuels, energy saving is a crucial requirement. Moreefficient trips can be achieved with travel-assistance systems (travel planners) [109], which provide real-time information on traffic, routes, public-transport options, available parking places, and charging points for EVs, among other features. A more sophisticated smart transport system could also implement traffic-demand-management tools. These schemes implement real-time speed-limit-control and traffic-signal-control optimization, for instance. The goal of this kind of information system is to optimize the journey and deliver a better and more-efficient travel experience for the user.

Another important concern about private transport in modern cities is parking. During rush hour, the traffic caused by cars searching for free parking spots constitutes up to $40 \%$ of the total traffic [110]. Smart parking systems have been proposed to address this problem, assisting drivers in finding and reserving the vacant parking spaces efficiently [111]. Research on automated vehicles is underway [112]. Automation in transport seeks to improve the safety and efficiency of mobility, highways and freeways being the first targets for this kind of vehicle [113].

Regarding public-transport systems, metropolitan transit (metro) systems are a preferred option in many cities for providing the required quality and quantity of service [132]. Several technologies and strategies for energy efficiency in urban rail systems can be found in the literature. A review of such solutions is presented in [133], where five main groups of actions 
C. Calvillo, A. Sánchez, J. Villar. Energy management and planning in smart cities. Renewable \& Sustainable Energy Reviews. vol. 55, pp. 273-287, March 2016. JCR: 8.050 (2016)

have been identified: regenerative braking, energy-efficient driving, comfort functions, traction efficiency, and smart measurement and management. Given the nature of the metro, with its numerous and frequent stops, regenerative braking can potentially provide important energy savings [134].

Another trend in public-transport efficiency is the change from diesel buses to electric or hybrid ones. Reference [140] analyses the benefits of urban electric buses in terms of costs and pollution, concluding that plug-in hybrid and electric city buses have the best potential to reduce energy consumption and emissions.

\subsection{Applications and research in transport systems}

Several applications of vehicles using cleaner fuels are mentioned in the literature. Starting with EVs, [114] provides a general overview of the tendencies, advantages, and disadvantages of such cars. Similarly, in [98], smart-charging strategies are proposed, and the impact on their externality costs such as emissions, health benefits, and energy dependence is analysed. A comprehensive review of hydrogen-fuelled cars and their infrastructure requirements is developed in [99], highlighting the limitations of other technologies and the possible benefits of using hydrogen as an energy carrier. Moreover, the author of reference [100] heavily criticizes fuel-cell vehicles, considering them an unfeasible solution in the short to medium term. From the biofuels perspective, the use of ethanol as a transportation fuel is studied in [101], considering environmental benefits, production, and political and economic aspects.

The travel planners designed to identify optimal travel routes are studied in [109], [115], and [116]. The first paper proposes a travel-assistance application for EV users, providing information on parking and recharging posts, among other things; however, the application is presented at the simulation level only. The second work implements an Internet-based optimal-route finder for public transport in Hong Kong. The third paper summarizes examples of other systems that have been successfully implemented in various cities. 
C. Calvillo, A. Sánchez, J. Villar. Energy management and planning in smart cities. Renewable \& Sustainable Energy Reviews. vol. 55, pp. 273-287, March 2016. JCR: 8.050 (2016)

Regarding goods delivery, a mathematical model for finding a distributor's optimal number and the time-window of service cycles is proposed in [137]. This model includes carbon emissions in its objective function and concludes that a compromise should be found between carbon costs and delivery times. Another interesting example of optimal delivery can be found in [138], where a multi-temperature food-distribution system is proposed for finding optimal delivery cycles for foods of different temperature ranges. Results suggest the applicability of such system, providing important cost reductions relative to conventional logistics.

Intelligent traffic management and congestion control have been addressed by many pieces of research. In [116], a congestion toll system for decreasing pollution is reviewed. Reference [118] analyses the emissions-decreasing potential of systems that have already been implemented in cities, such as flexible penalty mechanisms for transport and market mechanisms for private-car-ownership permissions. Similarly, references [117] and [119] deal with traffic-signal control. The former presents a real-time speed-limit-signal controller for emissions reduction. The latter proposes a multi-objective model with predictive traffic control, measuring the trade-offs among emissions, travel time, and cost. The main drawback of such systems is that they require an advanced information and communication infrastructure to apply the coordinated control proposed. To ease parking problems, an Internet-based reservation system is proposed in [111]. In addition, the potential of parking lots as charging posts for EVs is studied in [120], seeking to take advantage of people's working hours and the storage capabilities of EVs.

System architecture and the requirements for fully autonomous cars are reviewed in [112] and [113], including experimental results on highways.

Regenerative braking in public metro systems consists of recovering a vehicle's braking energy in the form of electricity so as to reuse it in the same vehicle or system (or another one). Three main strategies are implemented to maximize the use of this braking energy. For instance, an energy-wise optimal timetable is presented in [135], where a programming problem is designed to synchronize the braking of metro trains arriving at a station with the 
C. Calvillo, A. Sánchez, J. Villar. Energy management and planning in smart cities. Renewable \& Sustainable Energy Reviews. vol. 55, pp. 273-287, March 2016. JCR: 8.050 (2016)

departure of other trains within the same electrical section. This would allow the regenerated energy to be used directly to accelerate other trains without the need for storage. The second alternative comprises the use of energy-storage systems to save the braking energy. The authors in [134] analyse the main storage technologies for both on-board and wayside applications. The main benefit of this solution is that there is no need to synchronize trains, but the extra infrastructure for storage entails higher costs. Lastly, reversible substations can be implemented to return the braking energy to the grid, as in [136].

To sum up, Table 8 outlines the transport-related applications discussed in this section. The problems approached and the nature of solutions have a very broad scope, and many of them are complementary. Nevertheless, it is necessary to bear in mind that depending on the specific objectives of a smart city, certain solutions might provide controversial outcomes. For instance, a smart traffic-signal system can reduce total travel time for cars, promoting the use of such a transport system, but in the case of conventional-fuel vehicles, this could increase pollution. 
C. Calvillo, A. Sánchez, J. Villar. Energy management and planning in smart cities. Renewable \& Sustainable Energy Reviews. vol. 55, pp. 273-287, March 2016. JCR: 8.050 (2016)

Table 8. Summary of Transport systems application examples.

\begin{tabular}{|c|c|c|c|c|}
\hline Vehicle type & Ref. & Proposes & Objective & Reported outcome \\
\hline $\mathrm{EV}$ & [114] & $\begin{array}{l}\text { Discussion of } \\
\text { trends in PHEV } \\
\text { and other } \\
\text { technologies }\end{array}$ & $\begin{array}{l}\text { Autonomy and } \\
\text { economic } \\
\text { feasibility. }\end{array}$ & $\begin{array}{l}\text { Battery packs with an all- } \\
\text { electric range of } 32 \mathrm{~km} \\
\text { will yield up to a } 50 \% \\
\text { reduction in gasoline use. }\end{array}$ \\
\hline $\mathrm{EV}$ & [98] & $\begin{array}{l}\text { hydro-thermal unit } \\
\text { commitment for } \\
\text { different EV } \\
\text { scenarios }\end{array}$ & $\begin{array}{l}\text { Costs and } \\
\text { benefits of EVs } \\
\text { including } \\
\text { externalities }\end{array}$ & $\begin{array}{l}\text { Health accounts for } \\
\text { almost } 92 \% \text { of the total } \\
\text { benefit obtained from the } \\
\text { externalities. }\end{array}$ \\
\hline Hydrogen ICE & [99] & $\begin{array}{l}\text { Discussion of } \\
\text { different energy } \\
\text { technologies. }\end{array}$ & $\begin{array}{l}\text { Technical and } \\
\text { economic } \\
\text { feasibility }\end{array}$ & $\begin{array}{l}\text { It is required to develop a } \\
\text { solar hydrogen platform } \\
\text { with urgency. }\end{array}$ \\
\hline $\begin{array}{l}\text { Fuel cell } \\
\text { vehicle }\end{array}$ & {$[100]$} & $\begin{array}{l}\text { Discussion of } \\
\text { challenges in fuel } \\
\text { cell vehicles }\end{array}$ & $\begin{array}{l}\text { Technical and } \\
\text { economic } \\
\text { feasibility. }\end{array}$ & $\begin{array}{l}\text { Main challenge is to } \\
\text { produce hydrogen from } \\
\text { non-fossil fuels at a } \\
\text { reasonable cost. }\end{array}$ \\
\hline $\begin{array}{l}\text { Conventional } \\
\text { fuel vehicles }\end{array}$ & {$[101]$} & $\begin{array}{l}\text { Discussion of } \\
\text { opportunities and } \\
\text { challenges. }\end{array}$ & $\begin{array}{l}\text { Technical and } \\
\text { economic } \\
\text { feasibility. }\end{array}$ & $\begin{array}{l}\text { The major factor in } \\
\text { biodiesel production is } \\
\text { the feedstock ( } 75^{-80} \% \text { of } \\
\text { the total operating cost). }\end{array}$ \\
\hline $\mathrm{EV}$ & [109] & $\begin{array}{l}\text { Personal assistant } \\
\text { oriented to smart } \\
\text { cites and EVs }\end{array}$ & $\begin{array}{l}\text { Journey } \\
\text { efficiency and } \\
\text { user comfort }\end{array}$ & $\begin{array}{l}\text { Application for mobile } \\
\text { devices }\end{array}$ \\
\hline $\begin{array}{l}\text { Public } \\
\text { transport }\end{array}$ & {$[115]$} & $\begin{array}{l}\text { web-map public } \\
\text { transport enquiry } \\
\text { system }\end{array}$ & $\begin{array}{l}\text { Journey } \\
\text { efficiency and } \\
\text { user comfort }\end{array}$ & $\begin{array}{l}\text { The proposed system } \\
\text { matches at least } 95 \% \text { of } \\
\text { users' expectations. }\end{array}$ \\
\hline $\begin{array}{l}\text { Public } \\
\text { transport }\end{array}$ & [116] & $\begin{array}{l}\text { Analysis of smart } \\
\text { transport systems } \\
\text { trends. }\end{array}$ & $\begin{array}{l}\text { Real examples } \\
\text { developed in } \\
\text { several cities }\end{array}$ & $\begin{array}{l}\text { Several reported results. } \\
\text { Smart cities and } \\
\text { transport systems will be } \\
\text { important areas of } \\
\text { growth in the next years. }\end{array}$ \\
\hline $\begin{array}{l}\text { Conventional } \\
\text { fuel vehicles }\end{array}$ & [117] & $\begin{array}{l}\text { Smart traffic } \\
\text { control }\end{array}$ & $\begin{array}{l}\text { High way } \\
\text { speed limits to } \\
\text { reduce } \\
\text { emissions. }\end{array}$ & $\begin{array}{l}\text { Reduced travel time, total } \\
\text { emissions and maximum } \\
\text { dispersion levels of } \\
\text { emissions ( } 3.4 \%, 36 \% \text {, } \\
19 \% \text {, respectively). }\end{array}$ \\
\hline $\begin{array}{l}\text { Conventional } \\
\text { fuel vehicles }\end{array}$ & [118] & $\begin{array}{l}\text { Analysis of smart } \\
\text { traffic control } \\
\text { systems trends. }\end{array}$ & $\begin{array}{l}\text { GHG Emission } \\
\text { Reduction and } \\
\text { Traffic } \\
\text { Congestion } \\
\text { Control }\end{array}$ & $\begin{array}{l}\text { Policy suggestions on for } \\
\text { the Chinese urban } \\
\text { transport sector }\end{array}$ \\
\hline $\begin{array}{l}\text { Conventional } \\
\text { fuel vehicles }\end{array}$ & [119] & $\begin{array}{l}\text { Traffic control } \\
\text { system }\end{array}$ & $\begin{array}{l}\text { Reduce } \\
\text { emissions, } \\
\text { travel time and } \\
\text { cost. }\end{array}$ & $\begin{array}{l}\text { Reduction of } \mathrm{CO}_{2} \\
\text { emission by } 23.1 \% \text {, fuel } \\
\text { consumption is by } 28.2 \% \text {, } \\
\text { and total time spent by } \\
40.5 \% \text {. }\end{array}$ \\
\hline $\begin{array}{l}\text { Electric } \\
\text { vehicles }\end{array}$ & [120] & $\begin{array}{l}\text { Parking with smart } \\
\text { EV charging }\end{array}$ & $\begin{array}{l}\text { Minimize } \\
\text { emissions and } \\
\text { costs }\end{array}$ & $\begin{array}{l}\text { Payback time of 11years } \\
\text { for parking owner while } \\
\text { still benefiting the EV } \\
\text { owner. }\end{array}$ \\
\hline $\begin{array}{l}\text { Private and } \\
\text { public } \\
\text { transport }\end{array}$ & [112] & Vehicle automation & $\begin{array}{l}\text { Review of } \\
\text { advances in } \\
\text { different fields } \\
\text { of vehicle } \\
\text { automation. }\end{array}$ & $\mathrm{N} / \mathrm{A}$ \\
\hline $\begin{array}{l}\text { Private } \\
\text { vehicles }\end{array}$ & {$[113]$} & Vehicle automatioßo & $\begin{array}{l}\text { Hardware and } \\
\text { control } \\
\text { systems }\end{array}$ & Vehicle prototype. \\
\hline
\end{tabular}


C. Calvillo, A. Sánchez, J. Villar. Energy management and planning in smart cities. Renewable \& Sustainable Energy Reviews. vol. 55, pp. 273-287, March 2016. JCR: 8.050 (2016)

\section{Smart City Energy Models}

Energy-system models have been around for several decades and are experiencing constant evolution to incorporate new technologies, paradigms, and externalities (such as environmental concerns), as stated in [121]. From the energy perspective only, this kind of model is commonly used for power-system planning or for operation and management. An example of the former is reference [122], which presents a model for distribution-network expansion planning, considering the sizing, placement, and timing of DG investments and network reinforcements. Similarly, optimal DG allocation in a distribution network is studied in [123].

The operation of power systems can be exemplified as in [124], where a smart grid is simulated based on software agents; the simulation attempts to recreate the dynamic behaviour of a smart city, yet it considers only electricity. Other examples can be found in the distribution-network operation projects funded by the European Commission [125][127]. According to [128], electric-system modelling is normally carried out using some sort of stochastic programming, which involves minimizing an objective function subject to certain constraints. However, other techniques based on artificial intelligence, genetic algorithms, game theory, and so on, are also available.

\subsection{Urban-planning models and energy}

Besides the energy-based models for network planning and operation, the urban planning of a city (i.e., the land use and the design of an urban environment) can heavily influence its energy usage and the pollution it produces.

Indeed, urban infrastructure systems have extended lifespans and affect the inhabitants and the environment for long periods of time. Therefore, urban-planning models are of paramount importance for sustainable growth [143]. For instance, [145] proposes a model to assess a site's potential renewable-energy availability and urban energy-supply plants in order to determine the best places and type of generation to install given geographical constraints. A case study of a residential district in Korea is carried out to analyse its applicability. Similarly, 
C. Calvillo, A. Sánchez, J. Villar. Energy management and planning in smart cities. Renewable \& Sustainable Energy Reviews. vol. 55, pp. 273-287, March 2016. JCR: 8.050 (2016)

[144] proposes solutions for urban-planning improvements to energy efficiency that rely on information technologies. For instance, using geographic information systems (GIS) and 3D modelling to design buildings allows taking advantage of the terrain configuration (e.g., terrain slope: burying part of the building to reduce heating costs), orientation towards the sun (e.g., designing for greater sunlight exposure so as to increase interior temperatures during winter), and wind effects (e.g., considering the direction of wind to promote natural ventilation, reducing air-conditioning costs), among other things.

Reference [146] notes that many cities prioritize renewable energy or energy efficiency, as in the aforementioned examples; only a few cities approach urban planning through one strategy that facilitates synergy in energy-related activities at different scales. Moreover, greenhouse-gas emissions are not always present in urban-planning models [142].

References [141] and [142] analyse the carbon footprint in industrial and residential activities, respectively, and the possible prevention and mitigation solutions that can be carried out through urban-planning models. The former concludes that municipalities can have a decisive influence on the industrial carbon footprint because most reductions can be obtained through urban-planning decision variables, such as the location of industrial plants, waste deposits, transport networks, use of non-urbanizable areas, and so on. The latter mentions that the greatest pollutant source is transport, followed by gas and electricity consumption, and concludes that policymakers can reduce greenhouse-gas emissions by managing the infrastructure design and by including sustainability design criteria in master urban plans.

As mentioned in [146], individual efforts (designing and managing independent smart buildings, for instance) might not be optimal overall, as these tend to overlook many interactions between facilities - hence, the importance of an inclusive urban-planning project that considers full energy cycles that cut across all the presented intervention areas. 
C. Calvillo, A. Sánchez, J. Villar. Energy management and planning in smart cities. Renewable \& Sustainable Energy Reviews. vol. 55, pp. 273-287, March 2016. JCR: 8.050 (2016)

\subsection{Designing energy-system models in a smart-city context}

It is clear from the review developed throughout this paper that modelling a complete urban energy system is a complex task. However, some elements in all the intervention areas stand out in importance. This section provides several guidelines for the adequate modelling of such systems and describes the elements that should be taken into account.

Fig. 2 presents a general diagram of an energy-system model, including elements of all the intervention areas reviewed and the main required inputs (left) and expected outputs (right). Regarding the methodology for planning and operation, many approaches can be used, such as analytical, iterative, and hybrid methods. In [19], a classification of the different methodologies for distributed energy-resource dimensioning is provided.

The input information used in the model considerably affects the quality of results; hence, special attention should be paid to its selection. Table 9 provides a description of the main inputs needed for the successful design of the energy systems and of how these inputs affect the modelled system (e.g., in its profitability, in its performance). It is important to remark that despite the fact that certain inputs are more closely related to some aspects than others, all inputs are relevant to the final outcome. 
C. Calvillo, A. Sánchez, J. Villar. Energy management and planning in smart cities. Renewable \& Sustainable Energy Reviews. vol. 55, pp. 273-287, March 2016. JCR: 8.050 (2016)

Table 9. Energy system modeling. Input description and information sources.

\begin{tabular}{|c|c|c|c|}
\hline Input & Description & Mainly impacts on & $\begin{array}{l}\text { Typical information } \\
\text { source }\end{array}$ \\
\hline $\begin{array}{l}\text { Parameters and } \\
\text { resource } \\
\text { availability }\end{array}$ & $\begin{array}{l}\text { Performance parameters. (e.g. } \\
\text { electric efficiency, thermal } \\
\text { efficiency, power rating, losses) } \\
\text { and availability of the resource } \\
\text { when applicable (e.g. EV } \\
\text { connection times, DG } \\
\text { operation constrains) }\end{array}$ & $\begin{array}{l}\text { Performance } \\
\text { (constraints) of the } \\
\text { systems (e.g. } \\
\text { maximum } \\
\text { charge/discharge } \\
\text { rates of batteries). }\end{array}$ & $\begin{array}{l}\text { Research literature }([24] \text {, } \\
[25],[20]) \\
\text { SW tools }([30] \text { and }[27]) \\
\text { Datasheets }([32])\end{array}$ \\
\hline System costs & $\begin{array}{l}\text { All the necessary costs to } \\
\text { analyze economic feasibility of } \\
\text { systems (e.g. cost per installed } \\
\mathrm{kW} \text {, operation and } \\
\text { maintenance costs) }\end{array}$ & $\begin{array}{l}\text { Profitability of } \\
\text { systems (e.g. ROI, } \\
\text { payback times, } \\
\text { LCOE, etc.). }\end{array}$ & $\begin{array}{l}\text { Reports ([33], [17], [34]) } \\
\text { Retailer web pages }\end{array}$ \\
\hline $\begin{array}{l}\text { Geolocation } \\
\text { characteristics }\end{array}$ & $\begin{array}{l}\text { Natural sources information } \\
\text { (e.g. solar irradiation, wind } \\
\text { speed, rainfall) }\end{array}$ & $\begin{array}{l}\text { Production of the } \\
\text { systems (e.g. PV } \\
\text { production given the } \\
\text { solar irradiation } \\
\text { parameter). }\end{array}$ & $\begin{array}{l}\text { Specialized geographical } \\
\text { information systems } \\
\text { ([35], [36]) } \\
\text { Weather forecast } \\
\text { databases }([37],[38])\end{array}$ \\
\hline Energy prices & $\begin{array}{l}\text { The cost of energy for } \\
\text { comparative purposes (e.g. } \\
\text { retail energy tariffs, fuel costs, } \\
\text { price increment rate) }\end{array}$ & $\begin{array}{l}\text { Profitability of } \\
\text { systems (e.g. ROI, } \\
\text { payback times, } \\
\text { LCOE, etc.). }\end{array}$ & $\begin{array}{l}\text { Local utility web pages } \\
\text { Reports ([39]) }\end{array}$ \\
\hline $\begin{array}{l}\text { Regulatory } \\
\text { constraints }\end{array}$ & $\begin{array}{l}\text { All relevant constraints and } \\
\text { possibilities for the desired } \\
\text { location (e.g. retailing } \\
\text { conditions, selling energy back } \\
\text { to the grid) }\end{array}$ & $\begin{array}{l}\text { Operation } \\
\text { constraints of } \\
\text { systems. }\end{array}$ & Local regulation \\
\hline Energy demand & $\begin{array}{l}\text { Energy demand characteristics } \\
\text { for the desired application (e.g. } \\
\text { load curves) }\end{array}$ & $\begin{array}{l}\text { Sizing and operation } \\
\text { of systems (e.g. } \\
\text { installed capacity, } \\
\text { when to sell, buy, } \\
\text { store and/or transfer } \\
\text { energy) }\end{array}$ & Reports ([40], [41]) \\
\hline
\end{tabular}

Moreover, Table 9 presents some examples of the information sources that can be used for each input. The list of typical information sources is not intended to be exhaustive but rather to serve as guidance and to suggest possible sources of information.

\section{Concluding Remarks}

In order to achieve optimal energy management in a very complex system like a smart city, not only do most of its energy elements need to be identified and studied, but the implicit relations among them also have to be considered. Furthermore, detailed modelling and simulation are required to validate and improve existing and new systems. This paper 
C. Calvillo, A. Sánchez, J. Villar. Energy management and planning in smart cities. Renewable \& Sustainable Energy Reviews. vol. 55, pp. 273-287, March 2016. JCR: 8.050 (2016)

undertakes an extensive review of the existing approaches. On one hand, all the proposed energy-intervention areas within the city and their relations are considered; on the other hand, different currently available energy models and simulation tools are reviewed and compared.

Based on this study, some clear trends can be identified in all intervention areas. Benefiting from advances in technologies and reduced prices, DG (including energy storage and renewable sources) will continue to gain presence in the coming years. Energy-efficient facilities are making their way into future smart cities with better devices, control systems, and demand-response schemes. Similarly, tendencies show that the microgrid and smart-grid paradigms will become the standard in the long term. With respect to the transport sector, travel planners, parking assistants, and other similar system will be implemented, while EVs will surely find an important position in smart cities.

Models and simulators have been widely used in the urban context for many decades. This kind of tool is normally used for the operation and management of the systems or for planning expansion or the construction of the new systems. Current models are normally designed with specific objectives in mind, such as implementing traffic control, planning urban development, planning the expansion of generation capacity or transmission lines, and so on. Therefore, the elements considered are limited and they do not take into account many important interactions within the system.

The necessity of a holistic and comprehensive smart-city model has been highlighted by many authors. Even though it might be extremely difficult to integrate all the elements into a single computational model, it should at least consider all the intervention areas studied in this paper and include the most relevant stakeholders and technologies. Furthermore, the model should be applicable to any kind of city and be adaptable to new technologies and systems.

As discussed in this paper, there are many elements that should be taken into account while modelling energy systems; however, some of them are more critical than others. Special attention should be paid to an adequate selection of the system parameters and energy 
C. Calvillo, A. Sánchez, J. Villar. Energy management and planning in smart cities. Renewable \& Sustainable Energy Reviews. vol. 55, pp. 273-287, March 2016. JCR: 8.050 (2016)

constraints. Accurate geographical information about natural resources (wind, solar, etc.) is also important to the proper outcome of a planning process. Moreover, it has been demonstrated that the use of some sort of optimization algorithm considerably improves the expected benefits; hence, it is highly recommended that such approaches be followed. Lastly, considering the complexity of the systems, the objectives of the model should be clearly defined and prioritized. Addressing all these issues allows for the creation of a complete and adequate smart-city energy model, one that will assist decision makers in both government and industry to develop, simulate, and implement the best systems at minimum cost, fostering smarter and more-efficient cities.

\section{Acknowledgements}

The work of C. F. Calvillo was supported through an Erasmus Mundus Ph.D. Fellowship. The authors would like to express their gratitude to all partner institutions within the Erasmus Mundus Joint Doctorate Programme in Sustainable Energy Technologies and Strategies (SETS) as well as to the European Commission for their support.

\section{References}

[1] Chourabi, H., Taewoo Nam, S. Walker, J.R. Gil-Garcia, S. Mellouli, K. Nahon, T.A. Pardo, and H.J. Scholl. "Understanding Smart Cities: An Integrative Framework." In 2012 45th Hawaii International Conference on System Science (HICSS), 2289 -2297, 2012.

[2] IBM, "TheSmarterCity - ENERGY \& UTILITIES”, 03.ibm.com/innovation/us/thesmartercity/energy/index.html

[3] Morvaj, B., L. Lugaric, and S. Krajcar. "Demonstrating Smart Buildings and Smart Grid Features in a Smart Energy City." In Proceedings of the 2011 3rd International Youth Conference on Energetics (IYCE), $1-8,2011$.

[4] G.Chicco, P. Mancarella and. " $\mathrm{CO}_{2}$ Emission Reduction from Sustainable Energy Systems: Benefits and Limits of Distributed Multi-Generation." In: The Second Int. Conference on Bioenvironment, Biodiversity and Renewable Energies; 22 May 2011-27 May 2011; Venice. 2011., 2011.

[5] Cossent, R., T. Gómez, and P. Frías. "Towards a Future with Large Penetration of Distributed Generation: Is the Current Regulation of Electricity Distribution Ready? Regulatory Recommendations Under a European Perspective.” Energy Policy 37, no. 3 (March 2009): 1145-1155. doi:10.1016/j.enpol.2008.11.011. 
C. Calvillo, A. Sánchez, J. Villar. Energy management and planning in smart cities. Renewable \& Sustainable Energy Reviews. vol. 55, pp. 273-287, March 2016. JCR: 8.050 (2016)

[6] Méndez, V.H., J. Rivier, J.I. de la Fuente, T. Gómez, J. Arceluz, J. Marín, and A. Madurga. "Impact of Distributed Generation on Distribution Investment Deferral." International Journal of Electrical Power \& Energy Systems 28, no. 4 (May 2006): 244-252. doi:10.1016/j.ijepes.2005.11.016.

[7] Ruiz-Romero, Salvador, Antonio Colmenar-Santos, Francisco Mur-Pérez, and África López-Rey. "Integration of Distributed Generation in the Power Distribution Network: The Need for Smart Grid Control Systems, Communication and Equipment for a Smart City — Use Cases." Renewable and Sustainable Energy Reviews 38 (October 2014): 223-34. doi:10.1016/j.rser.2014.05.082.

[8] Cossent, Rafael, Tomás Gómez, and Luis Olmos. "Large-scale Integration of Renewable and Distributed Generation of Electricity in Spain: Current Situation and Future Needs." Energy Policy 39, no. 12 (December 2011): 8078-8087. doi:10.1016/j.enpol.2011.09.069.

[11] Kalogirou, Soteris A. "Solar Thermal Collectors and Applications." Progress in Energy and Combustion Science 30, no. 3 (2004): 231-295.

[12] Usaola, J. "Operation of Concentrating Solar Power Plants with Storage in Spot Electricity Markets." IET Renewable Power Generation 6, no. 1 (January 2012): 59 -66.

[13] Braunstein, A., and A. Kornfeld. "On the Development of the Solar Photovoltaic and Thermal (PVT) Collector." IEEE Transactions on Energy Conversion EC-1, no. 4 (December 1986): 31 -33.

[14] Karekezi S, Lata K, Coelho ST. Traditional biomass energy-improving its use and moving to modern energy use. In: Secretariat of the int. conference for renewable energies, Bonn, June 1-4; 2004.

[15] “Biofuels Legislation in Europe.” European Biofuels Technology Platform. Accessed September 30, 2013. http://www.biofuelstp.eu/legislation.html

[16] Hammons, T.J. "Geothermal Power Generation Worldwide." In Power Tech Conference Proceedings, 2003 IEEE Bologna, 1:8 pp. Vol.1, 2003.

[17] EPA, US. “CHP Technologies.” Accessed July 24, 2015. http://www.epa.gov/chp/technologies.html.

[18] Erdinc, O., and M. Uzunoglu. "Optimum Design of Hybrid Renewable Energy Systems: Overview of Different Approaches.” Renewable and Sustainable Energy Reviews 16, no. 3 (April 2012): 1412-25. doi:10.1016/j.rser.2011.11.011.

[19] Upadhyay, Subho, and M. P. Sharma. "A Review on Configurations, Control and Sizing Methodologies of Hybrid Energy Systems.” Renewable and Sustainable Energy Reviews 38 (October 2014): 47-63. doi:10.1016/j.rser.2014.05.057.

[20] Chauhan, Anurag, and R. P. Saini. “A Review on Integrated Renewable Energy System Based Power Generation for Stand-Alone Applications: Configurations, Storage Options, Sizing Methodologies and Control." Renewable and Sustainable Energy Reviews 38 (October 2014): 99-120. doi:10.1016/j.rser.2014.05.079.

[21] Adhikari, R.S., M. Buzzetti, and S. Magelli. "Solar Photovoltaic and Thermal Systems for Electricity Generation, Space Heating and Domestic Hot Water in a Residential Building." In 2011 International Conference on Clean Electrical Power (ICCEP), 461 -465, 2011.

[22] Chicco, Gianfranco, and Pierluigi Mancarella. “A Unified Model for Energy and Environmental Performance Assessment of Natural Gas-fueled Poly-generation Systems.” Energy Conversion and Management 49, no. 8 (August 2008): 2069-2077.

[23] Manfroi, G., M. Maistrello, and L. C. Tagliabue. "Synergy of Geothermal Heat Pumps and PV Plant for Buildings Block.” In 2011 Int. Conf. on Clean Electrical Power (ICCEP), 466-473, 2011.

[24] C. F. Calvillo, A. Sánchez-Miralles, and J. Villar. "Distributed Energy Generation in Smart Cities.” In 2013 International Conference on Renewable Energy Research and Applications (ICRERA), 161-66, 2013. doi:10.1109/ICRERA.2013.6749744. 
C. Calvillo, A. Sánchez, J. Villar. Energy management and planning in smart cities. Renewable \& Sustainable Energy Reviews. vol. 55, pp. 273-287, March 2016. JCR: 8.050 (2016)

[25] Calvillo, C. F., A. Sánchez, and J. Villar. "Evaluation and Optimal Scaling of Distributed Generation Systems in a Smart City," in 8th International Conference on Urban Regeneration and Sustanability, pp. 845-857, Putrajaya, Malaysia, 3-5 December 2013. doi:10.2495/SC130722.

[26] Connolly, D., H. Lund, B.V. Mathiesen, and M. Leahy. "A Review of Computer Tools for Analysing the Integration of Renewable Energy into Various Energy Systems.” Applied Energy 87, no. 4 (April 2010): 1059-82. doi:10.1016/j.apenergy.2009.09.026.

[27] Lambert, Tom, Paul Gilman, and Peter Lilienthal. "Micropower System Modeling with Homer." In Integration of Alternative Sources of Energy, edited by Felix A. Farret, 379-418. John Wiley \& Sons, Inc., 2005. http://onlinelibrary.wiley.com/doi/10.1002/0471755621.ch15/summary.

[28] Batas Bjelic, Ilija, and Rade M. Ciric. "Optimal Distributed Generation Planning at a Local Level - A Review of Serbian Renewable Energy Development.” Renewable and Sustainable Energy Reviews 39 (November 2014): 79-86. doi:10.1016/j.rser.2014.07.088.

[29] Sinha, Sunanda, and S. S. Chandel. "Review of Software Tools for Hybrid Renewable Energy Systems." Renewable and Sustainable Energy Reviews 32 (April 2014): 192-205. doi:10.1016/j.rser.2014.01.035.

[30]Berkeley Lab "Distributed Energy Resources Customer Adoption Model (DER-CAM).”. Accessed July 28, 2015. https://building-microgrid.lbl.gov/projects/der-cam

[31] Cardoso, G., M. Stadler, M. C. Bozchalui, R. Sharma, C. Marnay, A. Barbosa-Póvoa, and P. Ferrão. "Optimal Investment and Scheduling of Distributed Energy Resources with Uncertainty in Electric Vehicle Driving Schedules." Energy 64 (January 1, 2014): 17-30. doi:10.1016/j.energy.2013.10.092.

[32] SRCC, "Solar Rating \& Certification Corporation - Ratings", Accessed July 25, 2014. http://www.solar-rating.org/ratings/index.html.

[33] Fraunhofer ISE "Current and Future Cost of Photovoltaics. Long-term Scenarios for Market Development, System Prices and LCOE of Utility-Scale PV Systems." Study on behalf of Agora Energiewende (2015).

[34]H. Ossenbrink, T. Huld, A. Jäger-Waldau, N. Taylor, "Cost Maps for Unsubsidised Photovoltaic Electricity," European Commission, Joint Research Centre --- Institute for Energy and Transport, 2014.

[35]European Commission - Joint Research Centre, "Photovoltaic Geographical Information System Interactive Maps.” Accessed July 15, 2015. http://re.jrc.ec.europa.eu/pvgis/apps4/pvest.php

[36]IDAE, “Atlas Eólico de España”, Accessed Oct 15, 2014. http://atlaseolico.idae.es/meteosim

[37] "Data and Maps — European Environment Agency (EEA)." Folder. Accessed October 15, 2014. http://www.eea.europa.eu/data-and-maps.

[38] "Windfinder.com - Wind and Weather Forecasts and Reports." Windfinder.com. Accessed October 15, 2014. http://www.windfinder.com/forecasts.

[39] "Energy price statistics - Statistics explained." Eurostat. Accessed October 15, 2014. http://epp.eurostat.ec.europa.eu/statistics_explained/index.php/Energy price_statistics

[40] U.S. Energy Information Administration (EIA) “Annual Energy Outlook 2015 (AEO2015)," April, 2015.

[41]N. Pardo, K. Vatopoulos, A. Krook-Riekkola, J.A. Moya and A. Perez "Heat and cooling demand and market perspective," European Commission - Joint Research Centre, Institute for Energy and Transport, 2012.

[42] Maharjan, L., T. Yamagishi, and H. Akagi. "Active-Power Control of Individual Converter Cells for a Battery Energy Storage System Based on a Multilevel Cascade PWM Converter.” IEEE Transactions on Power Electronics 27, no. 3 (March 2012): 1099 -1107. doi:10.1109/TPEL.2010.2059045. 
C. Calvillo, A. Sánchez, J. Villar. Energy management and planning in smart cities. Renewable \& Sustainable Energy Reviews. vol. 55, pp. 273-287, March 2016. JCR: 8.050 (2016)

[43] Xu, Haifeng, I.U. Eronini, Zhi-Hong Mao, and A.K. Jones. "Towards Improving Renewable Resource Utilization with Plug-in Electric Vehicles.” In Innovative Smart Grid Technologies (ISGT), 2011 IEEE PES, 1 -6, 2011. doi:10.1109/ISGT.2011.5759189.

[44] Xing-guo, Tan, Wang Hui, and Li Qing-min. "Multi-port Topology for Composite Energy Storage and Its Control Strategy in Micro-grid." In Power Electronics and Motion Control Conference (IPEMC), 2012 7th International, 1:351 -355, 2012. doi:10.1109/IPEMC.2012.6258876.

[45] Ali, M.H., Bin Wu, and R.A. Dougal. "An Overview of SMES Applications in Power and Energy Systems." IEEE Transactions on Sustainable Energy 1, no. 1 (April 2010): 38 -47. doi:10.1109/TSTE.2010.2044901.

[46] Sebastián, R., and R. Peña-Alzola. "Control and Simulation of a Flywheel Energy Storage for a Wind Diesel Power System.” International Journal of Electrical Power \& Energy Systems 64 (January 2015): 1049-56. doi:10.1016/j.ijepes.2014.08.017.

[47] Mufti, Mairaj ud din, Shameem Ahmad Lone, Shiekh Javed Iqbal, Muzzafar Ahmad, and Mudasir Ismail. "Super-Capacitor Based Energy Storage System for Improved Load Frequency Control." Electric Power Systems Research 79, no. 1 (January 2009): 226-33. doi:10.1016/j.epsr.2008.06.001.

[48] Cristofari, C.; Notton, G.; Ezzat, M.; Stoyanov, L.; Canaletti, J.L.; Lazarov, V., "Pumped hydroelectric storage coupling wind-solar resources: A solution for increase ren on islands electrical grid," Energy and Sustainable Development: Issues and Strategies (ESD), 2010 Proceedings of the International Conference on , vol., no., pp.1,11, 2-4 June 2010

[49] “A Pollution-Free Hydrogen Economy? Not So Soon.” MIT Technology Review, n.d. By Richard A. Muller on July 11, 2003 http://www.technologyreview.com/news/401988/a-pollution-free-hydrogeneconomy-not-so-soon/.

[50] Olajire, Abass A. "CO2 Capture and Separation Technologies for End-of-pipe Applications - A Review.” Energy 35, no. 6 (June 2010): 2610-2628. doi:10.1016/j.energy.2010.02.030.

[51] Ma, Y., A. Kelman, A. Daly, and F. Borrelli. "Predictive Control for Energy Efficient Buildings with Thermal Storage: Modeling, Stimulation, and Experiments." IEEE Control Systems 32, no. 1 (February 2012): 44 -64. doi:10.1109/MCS.2011.2172532.

[52]Dunn, R.I., P.J. Hearps, and M.N. Wright. "Molten-Salt Power Towers: Newly Commercial Concentrating Solar Storage." Proceedings of the IEEE 100, no. 2 (February 2012): $504-515$. doi:10.1109/JPROC.2011.2163739.

[53] Madlener, Reinhard, and Jochen Latz. "Economics of Centralized and Decentralized Compressed Air Energy Storage for Enhanced Grid Integration of Wind Power." Applied Energy, Sustainable Development of Energy, Water and Environment Systems, 101 (January 2013): 299-309. doi:10.1016/j.apenergy.2011.09.033.

[54] Koohi-Kamali, Sam, N. A. Rahim, and H. Mokhlis. "Smart Power Management Algorithm in Microgrid Consisting of Photovoltaic, Diesel, and Battery Storage Plants Considering Variations in Sunlight, Temperature, and Load." Energy Conversion and Management 84 (August 2014): 562-82. doi:10.1016/j.enconman.2014.04.072.

[55] Goncalves de Oliveira, J.; Schettino, H.; Gama, V.; Carvalho, R.; Bernhoff, H., "Study on a doublyfed flywheel machine-based driveline with an $\mathrm{AC} / \mathrm{DC} / \mathrm{AC}$ converter," Electrical Systems in Transportation, IET , vol.2, no.2, pp.51,57, June 2012

[56] García-Villalobos, J., I. Zamora, J. I. San Martín, F. J. Asensio, and V. Aperribay. "Plug-in Electric Vehicles in Electric Distribution Networks: A Review of Smart Charging Approaches." Renewable and Sustainable Energy Reviews 38 (October 2014): 717-31. doi:10.1016/j.rser.2014.07.040. 
C. Calvillo, A. Sánchez, J. Villar. Energy management and planning in smart cities. Renewable \& Sustainable Energy Reviews. vol. 55, pp. 273-287, March 2016. JCR: 8.050 (2016)

[57]Pieltain Fernández, L., T.G.S. Román, R. Cossent, C.M. Domingo, and P. Frías. "Assessment of the Impact of Plug-in Electric Vehicles on Distribution Networks.” IEEE Transactions on Power Systems 26, no. 1 (2011): 206-213. doi:10.1109/TPWRS.2010.2049133.

[58] Villar, J., C.A. Diaz, J. Arnau, and F.A. Campos. "Impact of Plug-in-electric Vehicles Penetration on Electricity Demand, Prices and Thermal Generation Dispatch.” In European Energy Market (EEM), 2012 9th International Conference on The, 1-8, 2012. doi:10.1109/EEM.2012.6254808.

[59] Beer, S., T. Gomez, D. Dallinger, I. Momber, C. Marnay, M. Stadler, and J. Lai. "An Economic Analysis of Used Electric Vehicle Batteries Integrated Into Commercial Building Microgrids.” IEEE Transactions on Smart Grid 3, no. 1 (2012): 517-525. doi:10.1109/TSG.2011.2163091.

[60]I.J. Fernández, C. F. Calvillo, A. Sánchez-Miralles, and J. Boal. "Capacity Fade and Aging Models for Electric Batteries and Optimal Charging Strategy for Electric Vehicles.” Energy 60 (October 1, 2013): 35-43. doi:10.1016/j.energy.2013.07.068.

[61] Daryanian, B., Roger E. Bohn, and R.D. Tabors. “An Experiment in Real Time Pricing for Control of Electric Thermal Storage Systems.” IEEE Trans. on Power Systems 6, no. 4 (1991): 1356-1365.

[62] Karnouskos, S. "Demand Side Management via Prosumer Interactions in a Smart City Energy Marketplace.” In 2011 2nd IEEE PES International Conference and Exhibition on Innovative Smart Grid Technologies (ISGT Europe), 1 -7, 2011.

[63]"The Smart Grid: An Introduction." Accessed January 10, 2013. http://energy.gov/oe/downloads/smart-grid-introduction-0.

[64]Pieltain Fernández, L., T.G.S. Román, R. Cossent, C.M. Domingo, and P. Frías. "Assessment of the Impact of Plug-in Electric Vehicles on Distribution Networks.” IEEE Transactions on Power Systems 26, no. 1 (2011): 206-213. doi:10.1109/TPWRS.2010.2049133.

[65] Cossent, R., Olmos, L., Gómez, T., Mateo, C. and Frías, P., "Distribution network costs under different penetration levels of distributed generation.” Euro. Trans. Electr. Power, 21: 1869-1888, 2011. doi: 10.1002/etep.503

[66]Ding, Yi, P. Nyeng, J. Ostergaard, Maj Dang Trong, S. Pineda, Koen Kok, G.B. Huitema, and O.S. Grande. "Ecogrid EU - a Large Scale Smart Grids Demonstration of Real Time Market-based Integration of Numerous Small DER and DR.” In 2012 3rd IEEE PES International Conference and Exhibition on Innovative Smart Grid Technologies (ISGT Europe), 1-7, 2012. doi:10.1109/ISGTEurope.2012.6465895.

[67] San Román, Tomás Gómez, Ilan Momber, Michel Rivier Abbad, and Álvaro Sánchez Miralles. "Regulatory Framework and Business Models for Charging Plug-in Electric Vehicles: Infrastructure, Agents, and Commercial Relationships.” Energy Policy 39, no. 10 (October 2011): 6360-6375. doi:10.1016/j.enpol.2011.07.037.

[68] Choi, Tae-Seop, Kyung-Rok Ko, Seong-Chan Park, Young-Sik Jang, Yong-Tae Yoon, and Sang-Kug Im. "Analysis of Energy Savings Using Smart Metering System and IHD (in-home Display)." In Transmission Distribution Conference Exposition: Asia and Pacific, 2009, 1 -4, 2009.

[69] McHenry, Mark P. "Technical and Governance Considerations for Advanced Metering Infrastructure/smart Meters: Technology, Security, Uncertainty, Costs, Benefits, and Risks.” Energy Policy 59 (August 2013): 834-42. doi:10.1016/j.enpol.2013.04.048.

[70]Keebler, P.F. "Meshing Power Quality and Electromagnetic Compatibility for Tomorrow's Smart Grid.” IEEE Electromagnetic Compatibility Magazine 1, no. 2 (summer 2012): $100-103$.

[71] Rodriguez-Calvo, A., P. Frias, J. Reneses, and C. Mateo. "Optimal Degree of Smart Transformer Substations in Distribution Networks for Reliability Improvement.” In 2012 3rd IEEE PES International Conference and Exhibition on Innovative Smart Grid Technologies (ISGT Europe), 1-7, 2012. doi:10.1109/ISGTEurope.2012.6465733. 
C. Calvillo, A. Sánchez, J. Villar. Energy management and planning in smart cities. Renewable \& Sustainable Energy Reviews. vol. 55, pp. 273-287, March 2016. JCR: 8.050 (2016)

[72] European Comission, "Microgrids", http://www.microgrids.eu/index.php?page=kythnos\&id=2

[73] Guan, Xiaohong, Zhanbo Xu, and Qing-Shan Jia. "Energy-Efficient Buildings Facilitated by Microgrid.” IEEE Transactions on Smart Grid 1, no. 3 (December 2010): 243 -252.

[74] Bryan, J., R. Duke, and S. Round. "Decentralized Generator Scheduling in a Nanogrid Using DC Bus Signaling.” In IEEE Power Engineering Society General Meeting, 2004, 977-982 Vol.1, 2004.

[75] Pulselli, Riccardo Maria, Eugenio Simoncini, and Nadia Marchettini. "Energy and Emergy Based Cost-benefit Evaluation of Building Envelopes Relative to Geographical Location and Climate." Building and Environment 44, no. 5 (May 2009): 920-928.

[76] Dounis, A.I., and C. Caraiscos. "Advanced Control Systems Engineering for Energy and Comfort Management in a Building environment-A Review." Renewable and Sustainable Energy Reviews 13, no. 6-7 (August 2009): 1246-1261. doi:10.1016/j.rser.2008.09.015.

[77] Wang, Zhu, Rui Yang, Lingfeng Wang, R.C. Green, and A.I. Dounis. "A Fuzzy Adaptive Comfort Temperature Model with Grey Predictor for Multi-agent Control System of Smart Building.” In 2011 IEEE Congress on Evolutionary Computation (CEC), 728 -735, 2011.

[78] Byun, Jinsung, and Sehyun Park. "Development of a Self-adapting Intelligent System for Building Energy Saving and Context-aware Smart Services." IEEE Transactions on Consumer Electronics 57, no. 1 (February 2011): 90 -98. doi:10.1109/TCE.2011.5735486.

[79] Adda, R., O. Ray, S.K. Mishra, and A. Joshi. "Synchronous-Reference-Frame-Based Control of Switched Boost Inverter for Standalone DC Nanogrid Applications.” IEEE Transactions on Power Electronics 28, no. 3 (2013): 1219-1233. doi:10.1109/TPEL.2012.2211039.

[80] Poredos, A., and A. Kitanovski. "District Heating and Cooling for Efficient Energy Supply.” In 2011 International Conference on Electrical and Control Engineering (ICECE), 5238 -5241, 2011.

[81] Tao, Liang, C. Schwaegerl, S. Narayanan, and Jian Hui Zhang. "From Laboratory Microgrid to Real Markets \#x2014; Challenges and Opportunities.” In 2011 IEEE 8th International Conference on Power Electronics and ECCE Asia (ICPE ECCE), 264-271, 2011.

[82] Li, Juanjuan, Xiaoqing Zhou, and Yunfei Ding. “Analysis of Energy Demand of Building Envelope Modification Schemes in Hot-Humid Areas.” In International Conference on Energy and Environment Technology, 2009. ICEET '09, 1:27-32, 2009.

[83] Sozer, Hatice. "Improving Energy Efficiency Through the Design of the Building Envelope.” Building and Environment 45, no. 12 (December 2010): 2581-2593. doi:10.1016/j.buildenv.2010.05.004.

[84] "SmartHouse/SmartGrid." Accessed November 11, 2013. http://www.smarthouse-smartgrid.eu/

[85] "ENERgy Saving Information Platform for generation and consumption networks." Accessed November 11, 2013. http://www.enersip-project.eu/

[86] "I3RES - ICT based Intelligent management of Integrated RES for the Smart Grid optimal operation." Accessed November 11, 2013. https://www.citsem.upm.es/index.php/proyectoses?view=project $\&$ task $=$ show $\&$ id $=37$

[87] “SmartC2Net project." Accessed November 11, 2013. http://smartc2net.eu/

[88] "FINSENY project - future internet for smart energy." Accessed November 11, 2013. http://www.fippp-finseny.eu/

[89] "INTEGRIS: Intelligent Electrical Grid Sensor Communications." Accessed November 11, 2013. http://fp7integris.eu/index.php

[90] “GreenCom EU project.” Accessed November 11, 2013. http://www.greencom-project.eu/

[91] "Micro-Request-Based Aggregation, Forecasting and Scheduling of Energy Demand, Supply and Distribution(MIRABEL).” Accessed November 11, 2013. http://www.2020-horizon.com/MIRABELMicro-Request-Based-Aggregation-Forecasting-and-Scheduling-of-Energy-Demand-Supply-andDistribution(MIRABEL)-s9343.html. 
C. Calvillo, A. Sánchez, J. Villar. Energy management and planning in smart cities. Renewable \& Sustainable Energy Reviews. vol. 55, pp. 273-287, March 2016. JCR: 8.050 (2016)

[92]“ADVANCED.” Accessed November 11, 2013. http://www.advancedfp7.eu/

[93] “E+ Project.” Accessed November 11, 2013. http://eplusproject.eu/

[94]"BEYWATCH - Innovation seeds." $\quad$ Accessed November 11, 2013. http://www.innovationseeds.eu/Virtual_Library/Results/BEYWATCH.kl

[95]“BEAMS.” BEAMS. Accessed November 11, 2013. http://ict-beams.eu/besos-project-kick-off-inbarcelona/.

[96] “SmartHG.” Accessed November 11, 2013. http://smarthg.di.uniroma1.it/

[97] "EEPOS >> Energy management and decision support systems for Energy POSitive neighbourhoods." Accessed November 11, 2013. http://eepos-project.eu/

[98] Villar, Jose, Ignacio Trigo, Cristian A. Diaz, and Pablo Gonzalez. "Cost-benefit Analysis of Plug-in Electric Vehicles Penetration.” In European Energy Market (EEM), 2013 10th International Conference on The, 1-8, 2013. doi:10.1109/EEM.2013.6607287.

[99] Abbott, D. "Keeping the Energy Debate Clean: How Do We Supply the World's Energy Needs?" Proceedings of the IEEE 98, no. 1 (January 2010): $42-66$.

[100] Rogerson, S. "Road to Realism [fuel Cell Vehicles].” Power Engineer 19, no. 3 (July 2005): 24 -25. doi:10.1049/pe:20050304.

[101] Demirbas, Ayhan. "Political, Economic and Environmental Impacts of Biofuels: A Review." Applied Energy 86, Supplement 1, no. 0 (November 2009): S108-S117. doi:10.1016/j.apenergy.2009.04.036.

[102] "Nissan LEAF® All Electric Car." Nissan USA. Accessed September 16, 2013. http://www.nissanusa.com/electric-cars/leaf.

[103] "Toyota Prius 2013 Hybrid Car." Toyota USA. Accessed September 16, 2013. http://www.toyota.com/prius/\#!/Welcome

[104] “Are Hydrogen Cars Better Than Electric Ones? Sure, If You Can Find a Place to Fill It Up | Technology on GOOD." GOOD. Accessed September 16, 2013. http://www.good.is/posts/arehydrogen-cars-better-than-electric-ones-sure-if-you-can-find-a-place-to-fill-it-up.

[105] "Sufiy.: Better place: hydrogen vs. plug-in electric vehicles," Sufiy. Accessed September 16, 2013. http://sufiy.blogspot.com.es/2012/03/better-place-hydrogen-versus-plug-in.html

[106] Imai, S., N. Takeda, and Y. Horii. "Total Efficiency of a Hybrid Electric Vehicle.” In Power Conversion Conference - Nagaoka 1997., Proceedings of The, 2:947-950 vol.2, 1997. doi:10.1109/PCCON.1997.638381.

[107] "2014 Cruze Compact Car - Cruze Turbo Diesel | Chevrolet.” Www.chevrolet.com. Accessed September 16, 2013. http://www.chevrolet.com/cruze-compact-car.html.

[108] Klocke, F., D. Lung, R. Schlosser, B. Dobbeler, and S. Buchkremer. "Ecological Lifecycle Assessment of an Electric Drive for the Automotive Industry." In Electric Drives Production Conference (EDPC), 2012 2nd International, 1-6, 2012. doi:10.1109/EDPC.2012.6425130.

[109] Ferreira, J.C., and J.L. Afonso. "Mobi_System: A Personal Travel Assistance for Electrical Vehicles in Smart Cities.” In 2011 IEEE International Symposium on Industrial Electronics (ISIE), $1653-1658,2011$.

[110] P. White, "No Vacancy: Park Slopes Parking Problem And How to Fix It," February 27, 2007, http://www.transalt.org/newsroom/releases/126

[111] Wang, Hongwei, and Wenbo He. "A Reservation-based Smart Parking System." In 2011 IEEE Conference on Computer Communications Workshops (INFOCOM WKSHPS), 690 -695, 2011.

[112] Parent, Michel. “Advanced Urban Transport: Automation Is on the Way." IEEE Intelligent Systems 22, no. 2 (April 2007): $9-11$. 
C. Calvillo, A. Sánchez, J. Villar. Energy management and planning in smart cities. Renewable \& Sustainable Energy Reviews. vol. 55, pp. 273-287, March 2016. JCR: 8.050 (2016)

[113] Wang, Fei-Yue, P.B. Mirchandani, and Zhixue Wang. "The VISTA Project and Its Applications." IEEE Intelligent Systems 17, no. 6 (December 2002): 72 - 75. doi:10.1109/MIS.2002.1134364.

[114] Jones, W.D. "Take This Car and Plug It [plug-in Hybrid Vehicles].” IEEE Spectrum 42, no. 7 (July 2005): $10-13$.

[115] Pun-Cheng, L.S.C. “An Interactive Web-Based Public Transport Enquiry System With RealTime Optimal Route Computation.” IEEE Transactions on Intelligent Transportation Systems 13, no. 2 (June 2012): 983 -988. doi:10.1109/TITS.2011.2181501.

[116] Bodhani, A. "Smart Transport." Engineering Technology 7, no. 6 (July 2012): 70 -73.

[117] Zegeye, S.K., B. De Schutter, J. Hellendoorn, and E.A. Breunesse. "Reduction of Area-wide Emissions Using an Efficient Model-based Traffic Control Strategy." In 2011 IEEE Forum on Integrated and Sustainable Transportation System (FISTS), 239 -244, 2011.

[118] Xumei, Chen, Jiang Yulin, and Li Zhenyu. "Several Thoughts on GHG Emission Reduction and Traffic Congestion Control in Urban Transport." In 2011 International Conference on Management and Service Science (MASS), 1 -4, 2011. doi:10.1109/ICMSS.2011.5998300.

[119] S.K. Zegeye, B. De Schutter, J. Hellendoorn, and E.A. Breunesse, "Modelbased traffic control for the reduction of fuel consumption, emissions, and travel time," In Proceedings of mobil.TUM 2009

- International Scientific Conference on Mobility and Transport, Munich, Germany, 11 pp., May 2009.

[120] Tulpule, P., V. Marano, S. Yurkovich, and G. Rizzoni. "Energy Economic Analysis of PV Based Charging Station at Workplace Parking Garage.” In 2011 IEEE Energytech, 1 -6, 2011.

[121] Bhattacharyya, Subhes C., and Govinda R. Timilsina. "A Review of Energy System Models." International Journal of Energy Sector Management 4, no. 4 (November 23, 2010): 494-518. doi:10.1108/17506221011092742.

[122] Soroudi, Alireza, and Mehdi Ehsan. "A Distribution Network Expansion Planning Model Considering Distributed Generation Options and Techo-economical Issues.” Energy 35, no. 8 (August 2010): 3364-3374. doi:10.1016/j.energy.2010.04.022.

[123] Celli, G., and F. Pilo. "Optimal Distributed Generation Allocation in MV Distribution Networks.” In 22nd IEEE Power Engineering Society International Conference on Power Industry Computer Applications, 2001. PICA 2001. Innovative Computing for Power - Electric Energy Meets the Market, 81-86, 2001. doi:10.1109/PICA.2001.932323.

[124] Karnouskos, S., and T.N. de Holanda. "Simulation of a Smart Grid City with Software Agents." In Third UK Sim European Symposium on Computer Modeling and Simulation, 2009. EMS '09, 424-429, 2009. doi:10.1109/EMS.2009.53.

[125] "DISCERN - Distributed Intelligence for Cost-effective and Reliable Solutions." Accessed November 11, 2013. http://www.discern.eu/index.html

[126] "SUSTAINABLE: Smart distribution system operation for maximizing the integration of renewable generation." Accessed November 11, 2013. https://www.iit.upcomillas.es/proyectos/mostrar_proyecto.php.en?nombre_abreviado=SUSTAINAB LE_FP7

[127] "e-GOTHAM - Sustainable - Smart Grid Open System for THe Aggregated Control, Monitoring and Management of Energy." Accessed November 11, 2013. https://www.citsem.upm.es/index.php/proyectos-es?view=project\&task=show\&id=1

[128] Foley, A.M., B.P. Ó Gallachóir, J. Hur, R. Baldick, and E.J. McKeogh. "A Strategic Review of Electricity Systems Models.” Energy 35, no. 12 (December 2010): 4522-4530. doi:10.1016/j.energy.2010.03.057. 
C. Calvillo, A. Sánchez, J. Villar. Energy management and planning in smart cities. Renewable \& Sustainable Energy Reviews. vol. 55, pp. 273-287, March 2016. JCR: 8.050 (2016)

[129] Villar, J., C.A. Diaz, P. Gonzalez, and F.A. Campos. "Wind and Solar Integration with Plug-in Electric Vehicles Smart Charging Strategies.” In European Energy Market (EEM), 2014 11th International Conference on the 1-6, 2014. doi:10.1109/EEM.2014.6861265.

[130] Brenden, R.K., W. Hallaj, G. Subramanian, and S. Katoch. "Wind Energy Roadmap.” In Portland International Conf. on Management of Engineering Technology, 2009. PICMET 2009, 2548 -2562, 2009.

[131] Hable, M., C. Schwaegerl, Liang Tao, A. Ettinger, R. Köberle, and E.-P. Meyer. "Requirements on Electrical Power Infrastructure by Electric Vehicles." In Emobility - Electrical Power Train, 2010, 1 -6, 2010. doi:10.1109/EMOBILITY.2010.5668076.

[132] Vuchic, Vukan R. Urban Transit Systems and Technology. John Wiley \& Sons, 2007.

[133] González-Gil, A., R. Palacin, P. Batty, and J. P. Powell. “A Systems Approach to Reduce Urban Rail Energy Consumption." Energy Conversion and Management 80 (April 2014): 509-24. doi:10.1016/j.enconman.2014.01.060.

[134] A. González-Gil, R. Palacin, and P. Batty, "Sustainable urban rail systems: Strategies and technologies for optimal management of regenerative braking energy," Energy Conversion and Management, vol. 75, pp. 374-388, Nov. 2013.

[135] M. Peña-Alcaraz, A. Fernández, A. P. Cucala, A. Ramos, and R. R. Pecharromán, "Optimal underground tim design based on power flow for maximizing the use of regenerative-braking energy," Proceedings of the Institution of Mechanical Engineers, Part F: Journal of Rail and Rapid Transit, vol. 226, no. 4, pp. 397-408, Jul. 2012.

[136] Warin Y, Lanselle R, Thiounn M. Active substation. In: 9th World Congress on Railway Research - WCRR 2011. Lille, France; 2011.

[137] H.-C. Li, "Optimal delivery strategies considering carbon emissions, timedependent demands and demand-supply interactions," European Journal of Operational Research, vol. 241, no. 3, pp. 739-748, Mar. 2015.

[138] C.-I. Hsu, W.-T. Chen, and W.-J. Wu, "Optimal delivery cycles for joint distribution of multi-temperature food," Food Control, vol. 34, no. 1, pp. 106-114, Nov. 2013.

[139] L. Mirani, "Nobody in the fuel cell industry has ever made a profit-this CEO could be the first," Quartz. . http://qz.com/135032/fuelcell-energy-fuel-cell-profit/

[140] A. Lajunen, "Energy consumption and cost-benefit analysis of hybrid and electric city buses," Transportation Research Part C: Emerging Technologies, vol. 38, pp. 1-15, Jan. 2014.

[141] S. Zubelzu and R. Álvarez, "Urban planning and industry in Spain: A novel methodology for calculating industrial carbon footprints," Energy Policy, vol. 83, pp. 57-68, Aug. 2015. 
C. Calvillo, A. Sánchez, J. Villar. Energy management and planning in smart cities. Renewable \& Sustainable Energy Reviews. vol. 55, pp. 273-287, March 2016. JCR: 8.050 (2016)

[142] S. Zubelzu, R. Álvarez, and A. Hernández, "Methodology to calculate the carbon footprint of household land use in the urban planning stage," Land Use Policy, vol. 48, pp. 223-235, Nov. 2015.

[143] S. Malekpour, R. R. Brown, and F. J. de Haan, "Strategic planning of urban infrastructure for environmental sustainability: Understanding the past to intervene for the future," Cities, vol. 46, pp. 67-75, Aug. 2015.

[144] I. Marić, M. Pucar, and B. Kovačević, "Reducing the impact of climate change by applying information technologies and measures for improving energy efficiency in urban planning," Energy and Buildings.

[145] I.-A. Yeo and J.-J. Yee, "A proposal for a site location planning model of environmentally friendly urban energy supply plants using an environment and energy geographical information system (E-GIS) database (DB) and an artificial neural network (ANN)," Applied Energy, vol. 119, pp. 99-117, Apr. 2014.

[146] J. Lenhart, B. van Vliet, and A. P. J. Mol, "New roles for local authorities in a time of climate change: the Rotterdam Energy Approach and Planning as a case of urban symbiosis," Journal of Cleaner Production.

[147] B. Singh, V. Mukherjee, and P. Tiwari, "A survey on impact assessment of DG and FACTS controllers in power systems," Renewable and Sustainable Energy Reviews, vol. 42, pp. 846-882, Feb. 2015.

[148] K. L. Anaya and M. G. Pollitt, "The role of distribution network operators in promoting cost-effective distributed generation: Lessons from the United States of America for Europe," Renewable and Sustainable Energy Reviews, vol. 51, pp. 484-496, Nov. 2015.

[149] Z. Chen, L. Wu, and Y. Fu, "Real-Time Price-Based Demand Response Management for Residential Appliances via Stochastic Optimization and Robust Optimization," IEEE Transactions on Smart Grid, vol. 3, no. 4, pp. 1822-1831, Dec. 2012.

[150] The Energy Collective "Cost of Batteries for Electric Vehicles Falling More Rapidly than Projected" Accessed July 2015, http://www.theenergycollective.com/jessejenkins/2215181/cost-batteries-electric-vehicles-fallingmore-rapidly-projected 